SVERIGES RIKSBANK

WORKING PAPER SERIES

159

त्वित्र

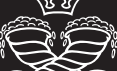

\title{
Do Higher Wages Cause Inflation?
}

Magnus Jonsson and Stefan Palmqvist APRIL 2004 
WORKING PAPERS ARE OBTAINABLE FROM

Sveriges Riksbank •Information Riksbank • SE-103 37 Stockholm Fax international: +4687870526

Telephone international: +4687870100

E-mail: info@riksbank.se

The Working Paper series presents reports on matters in the sphere of activities of the Riksbank that are considered to be of interest to a wider public.

The papers are to be regarded as reports on ongoing studies and the authors will be pleased to receive comments.

The views expressed in Working Papers are solely the responsibility of the authors and should not to be interpreted as reflecting the views of the Executive Board of Sveriges Riksbank. 


\title{
Do Higher Wages Cause Inflation?*
}

\author{
Magnus Jonsson ${ }^{\dagger}$ and Stefan Palmqvist ${ }^{\ddagger}$ \\ Sveriges Riksbank Working Paper Series \\ No. 159 \\ April 2004
}

\begin{abstract}
Much empirical evidence suggests that wage increases do not lead to inflation. This paper demonstrates that a 2 -sector dynamic general equilibrium model calibrated to the U.S. economy is able to explain this evidence. We quantify the effect of an increased wage-markup on the inflation rate in both the goods sector and the service sector. The mechanisms we emphasize and quantify are changes in relative prices and monetary policy. We find that our model is successful in explaining the empirical evidence. Quantitatively, the relative price effect is more important than monetary policy in mitigating the effect of higher wage-markups.
\end{abstract}

JEL classification: D43, E31, E52.

Keywords: Wage-markups, relative prices, monetary policy.

\footnotetext{
${ }^{*}$ We are grateful to Malin Adolfson, Susanto Basu, Jesper Lindé and Tommaso Monacelli for useful discussions and comments. We have also benefited from presenting the paper at Sveriges Riksbank. The views expressed in this paper are those of the authors and should not be interpreted as the views of the executive board of Sveriges Riksbank.

${ }^{\dagger}$ Corresponding author. Research Department, Sveriges Riksbank, SE-103 37 Stockholm, Sweden. Tel.: +468-787 01 43, e-mail: magnus.jonsson@riksbank.se.

${ }^{\ddagger}$ Monetary Policy Department, Sveriges Riksbank, SE-103 37 Stockholm, Sweden. E-mail: stefan.palmqvist@riksbank.se.
} 


\section{Introduction}

A common view among economists is that higher wages lead to inflationary pressures; the argument is well articulated by Layard, Nickell and Jackman (1994):

"[...] when buoyant demand reduces unemployment (at least relative to recent experienced levels), inflationary pressure develops. Firms start bidding against each other for labour, and workers feel more confident in pressing wage claims. If the inflationary pressure is too great, inflation starts spiraling upwards: higher wages lead to higher price rises, leading to still higher wage rises, and so on. This is the wage-price spiral."

In spite of the intuitive appeal of the argument the empirical evidence has turned out to be weak. In fact, the consensus in the empirical literature is that higher wage growth does not cause higher inflation. This evidence is summarized by Hess and Schweitzer (2000):

"There is little systematic evidence that wages (either conventionally measured by compensation or adjusted through productivity and converted to unit labor costs) are helpful for predicting inflation. [...] The current emphasis on using changes in wage rates to forecast shortterm inflation pressure would therefore appear unwarranted. The policy conclusion to be drawn is that inflation can appear regardless of recent wage trends."

The econometric literature has typically studied whether wage growth Granger-causes inflation. In accordance with the quotation from Hess and Schweitzer (2000) most studies have not found any strong indications that this is the case. Examples of such studies are Hogan (1998), Rissman (1995), Clark (1998) and Mehra (1993). On the other hand, Ghali (1999) finds strong evidence that wages Granger-cause prices. Aaronson (2001) finds that restaurant prices generally rise with changes in the wage bill. The empirical evidence is thus mixed, but still, most studies find a weak relationship between higher wage growth and higher inflation.

The purpose of this paper is to demonstrate that a 2-sector DGE model calibrated to the 
U.S. economy is able to explain the empirical evidence as summarized by Hess and Schweitzer (2000). To this end we quantify the effect of an increased wage-markup on the inflation rate in the goods sector and in the service sector. The mechanisms we emphasize and quantify are changes in relative prices and monetary policy.

Wages are surely an important factor in determining prices since they affect firms' marginal costs. However, we propose two reasons for why higher wages may not cause inflation. The first is monetary policy. If monetary policy actively tries to stabilize inflation, the effect of higher wages are presumably mitigated. To quantify this idea we compare a constant money supply rule with a Taylor rule. The second reason we propose is a relative price effect. Consider an economy characterized by labor unions with some market power when setting wages. If wage negotiations between labor unions and firms in different sectors of the economy are not coordinated, the relative price between the goods of the different sectors are also affected. This relative price effect will tend to dampen the effect on inflation.

Further, even if wage negotiations were coordinated different labor unions may have different market power. This may then lead to higher wage increases in sectors with relatively high market power. Whatever the reason, as long as wages are less than perfectly correlated, there will be a relative price effect.

The theoretical framework consists of a 2-sector dynamic general equilibrium model. Households have a degree of monopoly power over their own differentiated labor services. They can be thought of as organizing themselves in so called "craft" unions and acting as wage-setters in the labor market. ${ }^{1}$ They set the wage rate as a markup over the marginal rate of substitution between leisure and consumption. In the goods and capital markets they act as price takers though. The goods market is characterized by monopolistic competition. Each firm has

\footnotetext{
1 In a "craft" union households are organized by labor skill. An alternative framework is the "industrial" union structure where unions belong to a specific industry to which members supply labor, see Dixon and Rankin (1994).
} 
monopoly power over its differentiated good and sets the price as a markup over marginal costs. The firms act as price takers in the labor and capital markets. Money is introduced through a shopping time technology which is a simple way to model the fact that money facilitates transactions. Inflation is measured by the CPI and an optimal nominal price index, where the latter also includes the real wage rate.

The wage-markup is exogenous and determined by the elasticity of substitution between differentiated labor services. It is therefore possible to study how shocks to the wage-markup affect the inflation rate. ${ }^{2}$ Since the wage-markup is exogenous it is changes in the wage rate that cause changes in the inflation rate and not the other way around. Sensitivity analysis is performed with respect to adjustment costs for prices, wages and capital, habit formation as well as parameter values.

We find that if monetary policy follows a Taylor rule, a 1 percent increase in the wage-markup in the service sector leads to a 0.08 percentage points increase in the CPI while if the same shock hits the goods sector the effect is 0.05 percentage points. If inflation instead is measured by the optimal nominal price index the increase is about 0.10 percentage points higher. Our model is thus successful in replicating the empirical evidence stressed by Hess and Schweitzer (2000).

Quantitatively, the results suggest that the relative price effect is more important than monetary policy in mitigating the effect of higher wage-markups. The relative price effect dampens inflation by about 0.30 percentage points and the Taylor rule by about 0.20 percentage points compared to a constant money supply rule. These results turn out to be relatively insensitive to various adjustment costs and to reasonable changes in the parameter values.

The paper is organized as follows. In section 2 we present the two-sector dynamic general

\footnotetext{
${ }^{2}$ Formally it is the elasticity of substitution between the differentiated labor services that we assume follows an exogenous stochastic process. Since the wage-markup is only determined by the elasticity of substitution under flexible wages this is with no loss of generality. If wages are sticky, wage-markups are endogenous and it is not possible to study exogenous shifts in the wage-markup. For this reason we are looking at shocks to the elasticity of substitution throughout the paper. However, we still refer to them as markup shocks.
} 
equilibrium model and define our price measures. In section 3 we calibrate the model to broadly fit stylized facts of the U.S. economy. Section 4 reports our quantitative results from the impulseresponse analysis. Finally, section 5 concludes.

\section{Theoretical Framework}

The 2-sector model consists of a monetary authority (i.e., a central bank) and three types of private agents; retailers, households and firms. Households supply differentiated labor services and firms produce differentiated intermediate goods, facing the demand by the retailers. To make the model comparable to the standard, perfectly competitive, framework we assume that firms demand a composite labor service and households demand a composite good. The retailers then aggregate the differentiated labor services into a composite labor service and the differentiated intermediate goods into a composite good.

The two sectors of production are identical; to save on notation we therefore only describe sector 1 . However, we present the first order conditions for both sectors.

\section{$2.1 \quad$ Retailers}

There are two types of perfectly competitive retailers. There is free entry into this market, and thus, profits will be zero. The first type of retailers purchase labor inputs, $h^{i}$, from household $i$ at wage, $W^{i}$, in order to produce the composite labor, $h$. The maximization problem is given by

$$
\max _{h_{1}^{i}}\left[W_{1, t} h_{1, t}-\int_{0}^{1} W_{1, t}^{i} h_{1, t}^{i} d i\right]
$$

where $W$ denotes the nominal wage of the composite labor services. The differentiated labor services are aggregated according to a CES production function given by

$$
h_{1, t}=\left(\int_{0}^{1}\left(h_{1, t}^{i}\right)^{\frac{\eta_{w_{1}, t}-1}{\eta_{w_{1}, t}}} d i\right)^{\frac{\eta_{w_{1}, t}}{\eta_{w_{1}, t}-1}}
$$


where $\eta_{w_{1}}>1$ is the elasticity of substitution between the different inputs. We assume that the elasticity of substitution is time varying and follows an exogenous stochastic process. The first order condition yields the demand for labor services of household $i$

$$
h_{1, t}^{i}=\left(\frac{W_{1, t}}{W_{1, t}^{i}}\right)^{\eta_{w_{1}, t}} h_{1, t} .
$$

The retailers sell the composite labor to firms at a nominal wage, $W$, given by

$$
W_{1, t}=\left(\int_{0}^{1}\left(W_{1, t}^{i}\right)^{\frac{\eta_{w_{1}, t}}{\eta_{w_{1}, t-1}}} d i\right)^{\frac{\eta_{w_{1}, t-1}}{\eta_{w_{1}, t}}} .
$$

The second type of retailers produce an aggregated final good from intermediate inputs. The final good is used for consumption and investments by households. Formally, the maximization problem is

$$
\max _{y_{1}^{j}}\left[P_{1, t} y_{1, t}-\int_{0}^{1} P_{1, t}^{j} y_{1, t}^{j} d j\right]
$$

where $y$ denotes the quantity of the final good, $P$ the price of the final good, $y^{j}$ the input of intermediate good $j$, with $j \in[0,1]$, and $P^{j}$ the price of intermediate input $j$. The final good is produced according to a CES production function given by

$$
y_{1, t}=\left(\int_{0}^{1}\left(y_{1, t}^{j}\right)^{\frac{\eta_{p_{1}}-1}{\eta_{p_{1}}}} d j\right)^{\frac{\eta_{p_{1}}}{\eta_{p_{1}}-1}}
$$

where $\eta_{p_{1}}>1$ denotes the elasticity of substitution between goods. The first order condition for profit maximization yields the following demand function for input $j$

$$
y_{1, t}^{j}=\left(\frac{P_{1, t}}{P_{1, t}^{j}}\right)^{\eta_{p_{1}}} y_{1, t} ;
$$

that is, the price elasticity of the demand function is given by $\eta_{p_{1}}$. The composite good is sold to households at price, $P$, given by

$$
P_{1, t}=\left(\int_{0}^{1}\left(P_{1, t}^{j}\right)^{\frac{\eta_{p_{1}}}{\eta_{p_{1}}-1}} d j\right)^{\frac{\eta_{p_{1}}-1}{\eta_{p_{1}}}} .
$$




\subsection{Households}

The economy is inhabited by a continuum of households distributed on the unit interval, $i \in[0,1]$. Households are identical, except for the differentiated labor service they supply. Each household has preferences, $\mathcal{U}^{i}$, over two consumption goods, $c_{1}^{i}$ and $c_{2}^{i}$, and leisure, $\ell^{i}$, according to

$$
\mathcal{U}^{i}=\mathrm{E}\left[\sum_{t=0}^{\infty} \beta^{t} U\left(c_{1, t}^{i}, c_{2, t}^{i}, \ell_{t}^{i}\right)\right],
$$

where $t$ denotes time, E the unconditional expectation operator, $U(\cdot)$ the utility function, and $\beta \in(0,1)$ the subjective discount factor. We parameterize the utility-function as log-utility

$$
U\left(c_{1, t}^{i}, c_{2, t}^{i}, \ell_{t}^{i}\right)=\alpha \ln c_{t}^{i}+(1-\alpha) \ln \ell_{t}^{i}
$$

where $c^{i}$ is an aggregate of $c_{1}^{i}, c_{2}^{i}$ and $\alpha$ denotes the weight on consumption relative to leisure. The consumption aggregator is of the following form

$$
c_{t}^{i}=\left(c_{1, t}^{i}\right)^{\alpha_{1}}\left(c_{2, t}^{i}\right)^{\left(1-\alpha_{1}\right)},
$$

where $\alpha_{1}$ measures the weight given to $c_{1}^{i}$ relative to $c_{2}^{i}$.

The intertemporal budget constraint of household $i$, in nominal terms, is given by

$$
\begin{aligned}
& P_{1, t} c_{1, t}^{i}+P_{2, t} c_{2, t}^{i}+P_{1, t} i_{1, t}^{i}+P_{2, t} i_{2, t}^{i}+m_{t+1}^{i}+b_{t+1}^{i} \\
= & R_{1, t}^{k} k_{1, t}^{i}+R_{2, t}^{k} k_{2, t}^{i}+W_{1, t}^{i} h_{1, t}^{i}+W_{2, t}^{i} h_{2, t}^{i}+m_{t}^{i}+R_{t-1} b_{t}^{i}+T_{t}^{i}+\Pi_{t}^{j},
\end{aligned}
$$

where $k^{i}$ denotes the capital stock, $i^{i}$ investments (abusing notation somewhat), $R^{k}$ the nominal rental rate of capital, $m^{i}$ the money stock, $b^{i}$ one period nominal government bonds (in zero net supply in equilibrium), $R$ the nominal interest rate, $\Pi^{j}$ profits from firms producing intermediate inputs, and, finally, $T^{i}$ denotes transfers from the central bank; that is, the seigniorage. Throughout the paper capital letters denote aggregated per capita variables and lower caseletters individual decision variables. For prices; that is, $R^{k}, R, W, P$, capital letters denote 
nominal prices and lower-case letters denote real prices, where the latter is denoted in terms of units of good $1 .^{3}$

The households' time constraint is

$$
\ell_{t}^{i}+h_{t}^{i}+s_{t}^{i}=1
$$

where $s^{i}$ denotes time spent shopping. The time endowment is normalized to 1 .

Money is introduced through a shopping time technology following Ljungqvist and Sargent $(2000)$

$$
s_{t}^{i}=S\left(m_{t+1}^{i}, c_{t}^{i}, P_{1, t}, P_{2, t}\right)=\omega_{1}\left(\frac{m_{t+1}^{i}}{P_{1, t} c_{1, t}^{i}+P_{2, t} c_{2, t}^{i}}\right)^{-\omega_{2}},
$$

where $\omega_{1}$ and $\omega_{2}$ are parameters.

Finally, each household accumulates capital and rents it to the firms. The accumulation technologies in sector 1 and 2 are given by

$$
\begin{aligned}
& k_{1, t+1}^{i}=i_{1, t}^{i}+\left(1-\delta_{1}\right) k_{1, t}^{i}, \text { and } \\
& k_{2, t+1}^{i}=i_{2, t}^{i}+\left(1-\delta_{2}\right) k_{2, t}^{i},
\end{aligned}
$$

where $\delta$ denotes the constant rate of depreciation.

If we let good 1 be the numeraire, the first order conditions for the households can be summarized, in real terms, by the following seven conditions

$$
\begin{aligned}
p_{2, t} & =\frac{U_{c_{2, t}^{i}}^{\prime}-U_{\ell_{t}^{i}}^{\prime} S_{c_{2, t}^{i}}^{\prime}}{U_{c_{1, t}^{i}}^{\prime}-U_{\ell_{t}^{i}}^{\prime} S_{c_{1, t}^{i}}^{\prime}}, \\
w_{1, t} & =\nu_{w_{1}} \frac{U_{\ell_{t}^{i}}^{\prime}}{U_{c_{1, t}^{i}}^{\prime}-U_{\ell_{t}^{i}}^{\prime} S_{c_{1, t}^{i}}^{\prime}}, \\
w_{2, t} & =\nu_{w_{2}} \frac{U_{\ell_{t}^{i}}^{U_{c_{2, t}}^{\prime}}-U_{\ell_{t}^{i}}^{\prime} S_{c_{2, t}^{i}}^{\prime}}{U^{\prime}},
\end{aligned}
$$

\footnotetext{
rate.

${ }^{3}$ With a slight abuse of notation, we stick to the convention of letting $\Pi$ denote profits and $\pi$ the inflation
} 


$$
\begin{aligned}
U_{c_{1, t}^{i}}^{\prime}-U_{\ell_{t}^{i}}^{\prime} S_{c_{1, t}^{i}}^{\prime} & =\beta \mathrm{E}_{\mathrm{t}}\left(\left(U_{c_{1, t+1}^{i}}^{\prime}-U_{\ell_{t+1}^{i}}^{\prime} S_{c_{1, t+1}^{i}}^{\prime}\right)\left(r_{1, t+1}^{k}+1-\delta\right)\right), \\
U_{c_{2, t}^{i}}^{\prime}-U_{\ell_{t}^{i}}^{\prime} S_{c_{2, t}^{i}}^{\prime} & =\beta \mathrm{E}_{\mathrm{t}}\left(\left(U_{c_{2, t+1}^{i}}^{\prime}-U_{\ell_{t+1}^{i}}^{\prime} S_{c_{2, t+1}^{i}}^{\prime}\right)\left(\frac{r_{2, t+1}^{k}}{p_{2, t+1}}+1-\delta\right)\right), \\
U_{c_{1, t}^{i}}^{\prime}-U_{\ell_{t}^{i}}^{\prime} S_{c_{1, t}^{i}}^{\prime} & =\beta \mathrm{E}_{\mathrm{t}}\left(\frac{U_{c_{1, t+1}^{i}}^{\prime}-U_{\ell_{t+1}^{i}}^{\prime} S_{c_{1, t+1}^{i}}^{\prime}}{\pi_{1, t+1}}\right)-U_{\ell_{t}^{i}}^{\prime} S_{m_{t+1}^{i}}^{\prime}, \\
U_{c_{1, t}^{i}}^{\prime}-U_{\ell_{t}^{i}}^{\prime} S_{c_{1, t}^{i}}^{\prime} & =\beta \mathrm{E}_{\mathrm{t}}\left(\frac{\left(U_{c_{1, t+1}^{\prime}}^{\prime}-U_{\ell_{t+1}^{i}}^{\prime} S_{c_{1, t+1}^{i}}^{\prime}\right) R_{t}}{\pi_{1, t+1}}\right),
\end{aligned}
$$

where $\mathrm{E}_{\mathrm{t}}$ is the expectation operator conditional on information in period $t$ and

$$
\begin{aligned}
\pi_{1, t+1} & =\frac{P_{1, t+1}}{P_{1, t}}, \\
p_{2, t} & =\frac{P_{2, t}}{P_{1, t}}, \\
\nu_{w_{1}, t} & =\frac{\eta_{w_{1}, t}}{\eta_{w_{1}, t}-1}, \text { and } \\
\nu_{w_{2}, t} & =\frac{\eta_{w_{2}, t}}{\eta_{w_{2}, t}-1},
\end{aligned}
$$

where $\nu_{w}$ denotes the wage-markup. The first condition, (17), gives the familiar result that the marginal rate of substitution between good 1 and good 2 equals their relative price. Note that the marginal utility of consumption is reduced by the marginal disutility of having to shop for additional consumption. The next two conditions, (18) and (19), show how the households set the wage rate as a markup over the marginal rate of substitution between leisure and consumption. Conditions (20) and (21) are standard Euler equations relating consumption growth to the net return on capital. The final two conditions, (22) and (23), define the optimal level of money and bond holdings over time.

\section{$2.3 \quad$ Firms}

Firms produce intermediate goods. They act as monopolists and face the demand function $y_{1}^{j}$ for good $j$. Each good is produced by a single firm. The firms take the wage rate, the rental rate of capital and the prices of the other firms as given when choosing prices, labor and capital to 
maximize profits. There is no entry or exit and potential profits are allocated to the households. It is convenient to solve their maximization problem by first defining the cost function. Firm $j$ has a cost function for a given level of output defined by

$$
C\left(y_{1, t}^{j} ; R_{1, t}^{k}, W_{1, t}\right)=\min _{h_{1}^{j}, k_{1}^{j}}\left[W_{1, t} h_{1, t}^{j}+R_{1, t}^{k} k_{1, t}^{j}\right]
$$

subject to the increasing returns to scale production function

$$
y_{1, t}^{j}=Z_{1, t}\left(k_{1, t}^{j}\right)^{\theta_{1}}\left(h_{1, t}^{j}\right)^{1-\theta_{1}}-\chi_{1},
$$

where $Z_{1}$ denotes a stochastic technology shock common to all firms, $\chi_{1}$ a fixed cost independent of the scale of production and $\theta_{1}$ capital's share of output. The profit maximization problem can then be formulated in the following way

$$
\max _{P_{1, t}^{j}}\left[P_{1, t}^{j} y_{1, t}^{j}-C\left(y_{1, t}^{j} ; R_{1, t}^{k}, W_{1, t}\right)\right]
$$

The first order conditions and profits are given by

$$
\begin{aligned}
P_{1, t}^{j} & =\nu_{p_{1}} M C_{1, t}^{j}, \\
w_{1, t} & =\frac{1}{\nu_{p_{1}}}\left(1-\theta_{1}\right) Z_{1, t}\left(\frac{k_{1, t}^{j}}{h_{1, t}^{j}}\right)^{\theta_{1}}, \\
r_{1, t}^{k} & =\frac{1}{\nu_{p_{1}}} \theta_{1} Z_{1, t}\left(\frac{h_{1, t}^{j}}{k_{1, t}^{j}}\right)^{1-\theta_{1}}, \\
\Pi_{1, t}^{j} & =\left(1-\frac{1}{\nu_{p_{1}}}\right) Z_{1, t}\left(k_{1, t}^{j}\right)^{\theta_{1}}\left(h_{1, t}^{j}\right)^{1-\theta_{1}}-\chi_{1},
\end{aligned}
$$

where $M C^{j}$ denotes the marginal cost to firm $j$ of producing an additional unit of output, and $\nu_{p}$ denotes the price-markup; that is, $\nu_{p}=\frac{\eta_{p}}{\eta_{p}-1}$. These first order conditions say, among other things, that firms set their price as a markup over marginal cost. When solving for the equilibrium we assume a symmetric equilibrium where all firms produce at the same level, employ the same labor and capital, and charge the same relative price. 


\subsection{Adjustment Costs}

In the benchmark model presented so far we have not included any adjustment costs. As we show later in the paper the empirical fit of the model is improved by also including adjustment costs for capital and prices. The adjustment costs are assumed to be quadratic and zero in steady state, see for example Rotemberg (1982) and Ireland (2001). The specific functional forms are

$$
\begin{aligned}
& \frac{\kappa_{p_{1}}}{2}\left(\frac{P_{1, t}^{j}}{\bar{\pi}_{1} P_{1, t-1}^{j}}-1\right)^{2} y_{1, t}^{j} \text {, and } \\
& \frac{\kappa_{k_{1}}}{2}\left(\frac{i_{1, t}^{i}}{k_{1, t}^{i}}-\delta\right)^{2} k_{1, t}^{i},
\end{aligned}
$$

where $\kappa_{p_{1}}$ and $\kappa_{k_{1}}$ are parameters that quantify the cost of changing prices and the capital stock, respectively. The adjustment costs in sector 2 are defined equivalently.

\subsection{The Monetary Authority}

The money supply is determined by the following law of motion

$$
M_{t}^{s}=g_{t} M_{t-1}^{s}
$$

where $M^{s}$ denotes aggregate money supply and $g$ the growth rate of the money supply.

The monetary authority may either follow a rule for the growth rate of the money supply or a rule for the nominal interest rate. In the latter case, the growth rate of the money supply is endogenous. In the case where the monetary authority uses the money supply as its instrument, the rule is simply given by

$$
g_{t}=\bar{g},
$$

where $\bar{g}$ denotes the steady state money growth rate. ${ }^{4}$ This is a natural benchmark rule since there is no endogenous response of monetary policy in this case.

\footnotetext{
${ }^{4}$ A bar denotes a steady state value.
} 
In the case where the monetary authority uses the interest rate as its policy instrument, the rule is given by

$$
R_{t}=\bar{R}\left(\frac{\pi_{t}^{C P I}}{\bar{\pi}^{C P I}}\right)^{1.5}\left(\frac{Y_{t}}{Y_{t-1}}\right)^{0.5}
$$

where $R$ denotes the nominal interest rate and $\pi^{C P I}$ the inflation rate as measured by the consumer price index (to be defined in the next section). According to this rule the monetary authority follows the Taylor (1993) rule and reacts to both inflation and output.

We abstract from fiscal policy and nominal bonds are in zero supply; the monetary authority therefore simply fulfills the budget constraint

$$
T_{t}=M_{t}^{s}-M_{t-1}^{s}
$$

\subsection{Price Indices}

The focus of this paper is on the effect of variations in the wage-markup on nominal prices. We therefore need to define a nominal price index. There are numerous ways to do this. The most common price index in practice is the CPI. The CPI measures inflation as a weighted average of the nominal price changes of the different goods. In terms of our model CPI-inflation is calculated as

$$
\pi_{t}^{C P I}=\omega \pi_{1, t}+(1-\omega) \pi_{2, t}
$$

where $\omega$ is the weight placed on good 1 in the CPI. We determine the weight in the following way

$$
\omega=\frac{\bar{C}_{1}}{\bar{C}_{1}+\bar{p}_{2} \bar{C}_{2}}
$$

that is, the weight is set equal to the steady-state expenditure share of good 1.

For the purposes of our study it is instructive to notice that the CPI may also be calculated as

$$
\pi_{t}^{C P I}=\pi_{1, t}+(1-\omega) \Delta \ln p_{2, t}
$$


that is, we can separate the nominal price effect from the relative price effect.

Even though the CPI is the most used price index in practice, we also report results from a second measure, which we call the optimal nominal price index. To define this index, we draw upon the work by Obstfeld and Rogoff (1996), who define a consumption-based price index as

$$
\begin{aligned}
p_{t}^{c} & =\min \Upsilon_{t} \\
\text { s.t. } \tilde{C}_{t} & =1,
\end{aligned}
$$

where $p^{c}$ denotes the consumption-based price index, $\Upsilon$ the consumption expenditure and $\tilde{C}$ an aggregate of consumption and leisure. The consumption aggregate is given by

$$
\tilde{C}_{t}=\left[\left(C_{1, t}\right)^{\alpha_{1}}\left(C_{2, t}\right)^{\left(1-\alpha_{1}\right)}\right]^{\alpha}\left[L_{t}\right]^{(1-\alpha)}
$$

and the consumption expenditure by

$$
\Upsilon_{t}=C_{1, t}+p_{2, t} C_{2, t}+w_{t} L_{t}
$$

The solution is (neglecting a constant term)

$$
p_{t}^{c}=\left(p_{2, t}^{1-\alpha_{1}}\right)^{\alpha} w_{t}^{1-\alpha}
$$

Defined this way $p^{c}$ measures the units of a numeraire (here, good 1) necessary in a particular time period to purchase one optimal consumption-bundle consisting of all goods. We refer to this price index as an optimal real price index, since it measures the real price (units of good 1) of one unit of the optimal consumption basket. The consumption-based price index includes the wage rate in addition to the relative price of the two consumption goods, since leisure also is a good that derives utility.

The consumption-based price index measures how many units of good 1 that buys one optimal consumption basket consisting of consumption goods and leisure. Since $P_{1}$ measures 
the nominal price of good 1 , an optimal nominal price index, $P^{*}$, can then be defined as

$$
P_{t}^{*}=P_{1, t} p_{t}^{c}
$$

The optimal nominal price index thus measures the amount of money necessary to buy one optimal consumption basket. ${ }^{5}$ That an optimal price index for an inflation targeting central bank should include the wage rate has recently been suggested by Mankiw and Reis (2002). However, their motivation and theoretical framework is different from ours.

\subsection{Equilibrium}

We assume a symmetric and competitive equilibrium in which behavior is identical across households and across firms. This allows us to treat the economy as comprising of a representative household and a representative firm. An equilibrium consists of stochastic sequences of prices and quantities, such that:

1. Taking prices as given, retailers maximize profits subject to their constraints and given monetary policy.

2. Each household chooses consumption, investment, leisure, labor supply, capital and money holdings and shopping time to maximize its expected lifetime utility, subject to its constraints and given monetary policy.

3. Each firm chooses capital, labor and the price to maximize profits subject to its constraints and given monetary policy.

4. The monetary authority follows its money supply/interest rate rule and satisfies its budget constraint.

\footnotetext{
${ }^{5}$ The optimal nominal price index reduces to the CPI if the households do not derive any utility from leisure (i.e. if $\alpha=1$ ). Note also that the two indices will differ if the aggregation of consumption goods is different from the Cobb-Douglas aggregation we have assumed.
} 
5. In addition to aggregate consistency, the aggregate resource constraints hold and the capital, goods, labor and money markets clear.

To ensure the existence of a time-invariant decision rule, all variables need to be stationary. We abstract from exogenous steady state growth for the real variables since that simplifies and, in any case, would have small effects on our results. However, this model would be the detrended version of the same economy with exogenous technical progress and the discount factor adjusted for the growth rate. Nominal variables are detrended with the nominal price of good 1; that is, we assume that real money balances are stationary.

To find the decision rules, we use a numerical algorithm suggested by Uhlig (1999). This algorithm amounts to loglinearize the equilibrium conditions around steady state and then numerically solve the model by the method of undetermined coefficients.

\section{Calibration}

The model is calibrated to annual U.S. data for the period 1960-2001 (see the Data Appendix for a description of the data). We identify sector 1 as representing the goods sector (non-durables and durables), and sector 2 as the service sector. In terms of our model this means that $c_{1}$ is the consumption of goods, $i_{1}$ is investment in the goods-producing sector, and so on. In the following subsections we describe how the parameters in the model are calibrated. The full calibration is summarized in table 1 . To simplify the notation we only show equations for the goods sector, and note that all equations for the service sector can be found by replacing the subscript 1 by 2 .

The effective discount factor, $\beta$, is set to 0.96 , which implies an annual real interest rate in steady state of 4 percent, see Prescott (1986). We set $\alpha$ so that the average time an individual spends in employment is about $1 / 3$ of total time, which is the average time people between 18-64 
years spend in employment, see Juster and Stafford (1991). This implies that $\alpha=0.38$. The households' weight in the utility function on goods relative to services, $\alpha_{1}$, is estimated as

$$
\alpha_{1}=\frac{1}{42} \sum_{t=1960}^{2001} \frac{C_{1, t}}{C_{t}}
$$

which implies that $\alpha_{1}=0.45$.

To calibrate the scale parameter, $\omega_{1}$, in the shopping time technology we follow Pakko (1998). He notes that the fraction of the labor force employed in the finance, insurance and real estate sector was on average 6 percent during 1960-1980. Clearly, not all activities in these sectors are associated with shoe-leather costs of inflation. To get a crude measure we follow Pakko and cut this number in half and set $\omega_{1}$ to make households spend 3 percent of their time shopping. This implies a value of $\omega_{1}$ equal to 0.003 . The curvature parameter, $\omega_{2}$, is set equal to 1.0 which implies an interest rate elasticity of money demand equal to its conventionally measured value of one-half.

The real depreciation rates in each sector are set equal to their historical averages, which implies that $\delta_{1}=0.07$ and $\delta_{2}=0.03$. Labor's share of output in the goods sector is computed as

$$
\left(1-\theta_{1}\right)=\frac{1}{42} \sum_{t=1960}^{2001} \frac{w_{1, t} H_{1, t}}{Y_{1, t}} .
$$

This gives $\theta_{1}=0.48$, and $\theta_{2}=0.38$. Thus, we find that the production of goods is more capital intensive than the production of services, which seems plausible. These estimates are somewhat higher than those that appear elsewhere in the literature (typically 0.36) since we exclude government consumption and net exports from our measure of GDP.

To get an estimate of the average price-markups, we write the final goods production-function in the goods sector as Hornstein (1993); that is,

$$
\Delta \ln Y_{1, t}=\nu_{p_{1}}\left(\theta_{1} \Delta \ln K_{1, t}+\left(1-\theta_{1}\right) \Delta \ln H_{1, t}+\Delta \ln Z_{1, t}\right)
$$


We insert the computed capital intensities from above and estimate (51) by OLS to get the average price-markup in the two sectors. This gives us the average price-markups as $\bar{\nu}_{p_{1}}=1.22$, and $\bar{\nu}_{p_{2}}=1.27$. To get the Solow-residuals we use the OLS-residuals, divide these by the estimated average price-markup in each sector and transform them into log-levels.

To compute the time-varying wage-markups, we follow the procedure suggested by Galí, Gertler and López-Salido (2000),

$$
\begin{aligned}
\nu_{w_{1}, t} & =\frac{w_{1, t} L_{t}}{C_{1, t}} \frac{\alpha}{1-\alpha} \alpha_{1}, \text { and } \\
\nu_{w_{2}, t} & =\frac{w_{2, t} L_{t}}{C_{2, t}} \frac{\alpha}{1-\alpha}\left(1-\alpha_{1}\right) .
\end{aligned}
$$

which gives us a time-series of wage-markups in the goods sector and the service sector. The average of the wage-markups computed this way are $\bar{\nu}_{w_{1}}=1.06$, and $\bar{\nu}_{w_{2}}=1.09$.

To pin down the fixed cost, $\chi$, we assume that profits are zero in steady state, which implies that

$$
\chi_{1}=\left(1-\frac{1}{\bar{\nu}_{p_{1}}}\right)\left(\bar{k}_{1}\right)^{\theta_{1}}\left(\bar{h}_{1}\right)^{1-\theta_{1}} .
$$

Having computed the wage-markups and Solow-residuals (in levels) we first convert the wagemarkups into elasticities of substitution, using that the elasticity of substitution can be written as $\eta_{w}=\nu_{w} /\left(\nu_{w}-1\right)$. We then take the logarithm of the elasticities of substitution and apply a HP-filter to the log of the elasticities of substitution as well as the Solow-residuals, so that all variables are expressed as percent deviations from their steady state-values. Finally, we estimate an unrestricted VAR-model containing these four variables, which gives

$$
\left[\begin{array}{c}
\hat{\eta}_{w_{1}, t} \\
\hat{\eta}_{w_{2}, t} \\
\hat{z}_{1, t} \\
\hat{z}_{2, t}
\end{array}\right]=\left[\begin{array}{cccc}
-0.03 & 0.18 & 0.39 & 0.12 \\
-0.53 & 0.77 & -0.04 & -0.19 \\
-0.12 & 0.14 & 0.43 & 0.20 \\
-0.35 & 0.37 & -0.32 & 0.55
\end{array}\right]\left[\begin{array}{c}
\hat{\eta}_{w_{1}, t-1} \\
\hat{\eta}_{w_{2}, t-1} \\
\hat{z}_{1, t-1} \\
\hat{z}_{2, t-1}
\end{array}\right]+\left[\begin{array}{c}
\varepsilon_{1, t} \\
\varepsilon_{2, t} \\
\varepsilon_{3, t} \\
\varepsilon_{4, t}
\end{array}\right]
$$

where the hats denote that these are measured as percent deviation from steady-state. The 
estimated variance-covariance matrix of the reduced form residuals is

$$
E\left(\varepsilon \varepsilon^{\prime}\right)=\left[\begin{array}{llll}
0.00021 & 0.00007 & 0.00006 & 0.00005 \\
0.00007 & 0.00035 & 0.00013 & 0.00018 \\
0.00006 & 0.00013 & 0.00015 & 0.00012 \\
0.00005 & 0.00018 & 0.00012 & 0.00021
\end{array}\right] \text {. }
$$

This estimated driving-process is used to generate elasticities of substitution and Solow-residuals that we feed into our calibrated model.

Bils and Klenow (2002) show that prices on goods are changed about every quarter, whereas prices on services are changed about every half year. Since our model is annual we therefore let $\kappa_{p_{1}}=0$, whereas we calibrate $\kappa_{p_{2}}$ such that prices on services are changed about once a year. This implies that $\kappa_{p_{2}}=3.60$. The adjustment costs for capital is set such that the volatility of investments in the model equal those in the data. Our benchmark calibration implies that investment in the goods sector are less volatile than in the data. Hence, we assume that $\kappa_{k_{1}}=0$. To match the volatility of investments in the service sector we let $\kappa_{k_{2}}=4.50 .^{6}$

Tables 2 and 3 show simulated moments from the model together with their empirical counterparts. Table 2 presents moments from the benchmark model with no adjustment costs while table 3 presents moments from the model with adjustment costs for capital and prices. Both tables include simulations from a constant money supply rule and a Taylor rule. The moments of most importance to this study are the ones that include the CPI, the wage-markups and the nominal wage. By casual inspection we conclude that the Taylor rule performs better than the constant money supply rule in general and that adjustment costs for prices and capital improve the empirical fit of the model.

The correlations between the CPI and the wage-markups in sector 1 and 2 are of particular interest since we ultimately want to study these relationships. In the data these correlations

\footnotetext{
${ }^{6}$ The introduction of nominal price rigidities using quadratic adjustment costs is equivalent to Calvo (1983)style nominal price contracts up to a first order approximation, see Dib (2002) appendix C. The ratio $\frac{\eta_{p}-1}{\kappa_{p}}$ can therefore be interpreted, at the aggregate level, as the fraction of firms that can adjust their price in any given period. A value of $\kappa_{p_{2}}=3.60$ implies that the average duration of a price contract is one year.
} 
are positive and higher in sector 2 than in sector 1 . The correlation coefficient is 0.29 in sector 1 and 0.71 in sector 2 . The model with adjustment costs is able to replicate these correlations both under a constant money supply rule and a Taylor rule. The benchmark model performs somewhat worse in this respect, in particular under a Taylor rule when the correlation between the CPI and the wage-markup in sector 1 is negative. It still captures the qualitative result though; that is, the correlation is more positive in sector 2 than in sector 1 .

The correlation between the CPI and the nominal wage is well replicated by the adjustment cost model, both in the aggregate and in the sectors. In the data the correlations vary between 0.61 and 0.66 and in the models between 0.37 and 0.49 . In the benchmark model the results are somewhat disappointing. In particular this is true under a money supply rule, where the correlations are strongly negative.

The standard deviation of the nominal wage relative to the standard deviation of the CPI is 0.71 in the aggregate and 0.91 and 0.69 in sector 1 and sector 2, respectively. In the models with adjustment costs the relative standard deviations vary between 0.73 and 0.76 . Again the benchmark model with a constant money supply rule performs poorly with a relative standard deviation of about 1.50 .

The overall picture regarding the real moments is comparable with other 1-sector DGEmodels, see for example Cooley and Prescott (1995). The models are successful in replicating much of the relative standard deviations and correlations in consumption, investments and hours worked. Where the models fail though, is to explain the relative standard deviation of consumption to output. 


\section{Quantitative Analysis}

This section investigates the impulse-response of a 1 percent shock to the wage-markup, in the goods sector and the service sector, respectively, on the inflation rate. This is intended to capture what happens if a union in one sector of the economy unilaterally raises the wage rate for its members above what is motivated by productivity. We then quantify what happens when the wage-markups in both sectors change. Shocks to the wage-markups in the goods sector and the service sector are estimated in a VAR-model. To check the robustness of the results, sensitivity analysis is performed with respect to various adjustment costs and parameter values.

\subsection{A Permanent 1 Percent Increase in the Wage-Markup}

The focus of this paper is on how relative prices and monetary policy affect the inflation rate after a shock to the wage-markup. Results from both exogenous monetary policy (i.e., a constant money supply rule) and endogenous monetary policy (i.e., a Taylor rule) are therefore reported. In order to disentangle relative price changes from nominal price changes we report the following variables: $\pi_{t}^{\text {omega }}=100(1-\omega)\left(\frac{p_{2, t}}{p_{2, t-1}}-1\right), \pi_{t}^{\mathrm{c}}=100\left(\frac{p_{t}^{c}}{p_{t-1}^{c}}-1\right), \pi_{t}^{*}=100\left(\frac{p_{t}^{*}}{p_{t-1}^{*}}-1\right)$, and the growth rate of the nominal price of good 1 defined as (slightly abusing notation) $\pi_{1, t}=$ $100\left(\frac{P_{1, t}}{P_{1, t-1}}-1\right)$. When inflation is measured by the CPI, $\pi^{\text {omega }}$ measures the relative price effect. In the case when inflation is measured by the optimal index, $\pi^{\mathrm{c}}$ measures the relative price effect. In both cases, $\pi_{1}$ measures the nominal price effect. Results are presented from the benchmark model, see figures 1 and 2, and from the model with adjustment costs, see figures 3 and 4 .

Figures $1 \mathrm{a}$ and $1 \mathrm{~b}$ show the response of inflation and relative prices to a 1 percent increase in the wage-markup in the goods sector under a constant money supply rule. This leads to a nominal price change as well as a relative price change. Firms in the goods sector raise their 
goods prices since marginal costs increase; $\pi_{1}$ increases by 0.5 percentage points, see figure 1b. The increased price of goods gives households incentive to increase their consumption of services. The substitution from goods to services changes the relative price; $\pi^{\text {omega }}$ decreases by 0.27 percentage points. Taken together this means that a 1 percent increase in the wagemarkup leads to a rise in the CPI of 0.22 percentage points. The optimal price index rises by 0.34 percentage points; that is, the effect of a higher wage rate is about 0.10 percentage points. In the case of a Taylor rule the rise in the CPI is only about 0.05 percentage points, figures $1 \mathrm{c}$ and $1 \mathrm{~d}$. This illustrates that if the monetary authority follows a simple monetary policy rule there is practically no effect on the CPI of higher wage-markups. The increase in the optimal price index is still about 0.10 percentage points higher than the CPI.

Figure 2 displays the responses of a shock to the wage-markup in the service sector. By comparing figure $2 \mathrm{a}$ with $1 \mathrm{a}$ and $2 \mathrm{c}$ with $1 \mathrm{c}$ it can be seen that the quantitative effects are very similar to a wage-markup shock in the goods sector. The only noticeable difference is a slightly larger increase in the CPI from a shock in the service sector than in the goods sector. The reason for this is that the service sector is slightly larger than the goods sector.

Results from the model with adjustment costs are displayed in figures 3 and 4 . Figure 3 shows the responses of a shock to the wage-markup in the goods sector. Since there are no adjustment costs in this sector the results are very similar to the benchmark case, see figure 1. A similar shock in the service sector is displayed in figure 4. Compared to the benchmark case the increase in the CPI is dampened, both under a constant money supply rule and under a Taylor rule. This is due to the price stickiness. 


\subsection{Estimated Shocks to the Wage-Markup}

The elasticity of substitution between labor inputs in the goods and the service sector is used to estimate a VAR-model. ${ }^{7}$ If we let the elasticity of substitution in the goods sector be ordered first, we get the following system

$$
\left[\begin{array}{l}
\hat{\eta}_{w_{1}, t} \\
\hat{\eta}_{w_{2}, t}
\end{array}\right]=\left[\begin{array}{cc}
0.17 & 0.35 \\
-0.56 & 0.64
\end{array}\right]\left[\begin{array}{c}
\hat{\eta}_{w_{1}, t-1} \\
\hat{\eta}_{w_{2, t-1}}
\end{array}\right]+\left[\begin{array}{c}
\varepsilon_{1, t} \\
\varepsilon_{2, t}
\end{array}\right] .
$$

The estimated variance-covariance matrix of the reduced form residuals is

$$
E\left(\varepsilon \varepsilon^{\prime}\right)=\Sigma=\left[\begin{array}{ll}
0.00023 & 0.00006 \\
0.00006 & 0.00034
\end{array}\right]
$$

To construct disturbance vectors with the estimated $\Sigma$ as their variance-covariance matrix we first define the matrix $\Psi$, where $\Psi$ is the lower triangular Cholesky decomposition of the estimated $\Sigma$ matrix. We then multiply $\Psi$ with a constant to make the wage-markup increase by 1 percent in the initial period. Since the Cholesky decomposition depends on the ordering of the variables in the VAR-model we also present the results with a different ordering.

In figures $5 \mathrm{a}$ and $5 \mathrm{~b}$, a 1 percent shock to the wage-markup in the goods sector is shown. The wage-markup in the service sector falls since it is negatively correlated with the wage-markup in the goods sector. Since the two wage-markups counteract each other the impact on the CPI is likely to be small. In the case of a constant money supply rule the effect is essentially zero, see figure 5a. Under a Taylor rule the response of the CPI is more complicated, see figure 5b. In the first period the CPI is unaffected but in the second period it falls by 0.19 percentage points and in the third it increases to 0.08 percentage points before it returns to zero.

Figures $5 \mathrm{c}$ and $5 \mathrm{~d}$ display the response of the same shock applied to the wage-markup in the service sector. In this case the CPI rises by 0.25 percentage points initially if the monetary follows a constant money supply rule, see figure $5 \mathrm{c}$. Figure $5 \mathrm{~d}$ shows the results under a Taylor

\footnotetext{
${ }^{7}$ Note that shocks to the elasticity of substitution between different labor inputs and shocks explictly to the wage-markups are equivalent under flexible wages.
} 
rule. In the first period the CPI rises by 0.22 percentage points, in the second it falls to -0.28 percentage points before it gradually returns to zero.

These results indicate that wage-markup shocks in the service sector are more important than similar shocks in the goods sector. It is clearly so if monetary policy follows a constant money supply rule. It is also the case under a Taylor rule but to a lesser extent.

The ordering of the variables may matter for the Cholesky decomposition and therefore for the results. To investigate this possibility, simulations where the ordering of the variables are changed are also performed; that is, the elasticity of substitution in the service sector is ordered first. This gives the following system

$$
\left[\begin{array}{l}
\hat{\eta}_{w_{2}, t} \\
\hat{\eta}_{w_{1}, t}
\end{array}\right]=\left[\begin{array}{cc}
0.64 & -0.56 \\
0.35 & 0.17
\end{array}\right]\left[\begin{array}{l}
\hat{\eta}_{w_{2}, t-1} \\
\hat{\eta}_{w_{1}, t-1}
\end{array}\right]+\left[\begin{array}{l}
\varepsilon_{2, t} \\
\varepsilon_{1, t}
\end{array}\right],
$$

with an estimated reduced form variance-covariance matrix

$$
E\left(\varepsilon \varepsilon^{\prime}\right)=\Sigma=\left[\begin{array}{ll}
0.00034 & 0.00006 \\
0.00006 & 0.00023
\end{array}\right]
$$

Figures $6 \mathrm{a}$ and $6 \mathrm{~b}$ display the response of the CPI to a shock in the service sector. Under a constant money supply rule the CPI increases by 0.10 percentage points, figure $6 \mathrm{a}$. Under a Taylor rule the CPI rises by 0.08 percentage points in the first period and falls to -0.09 percentage points in the second, figure $6 \mathrm{~b}$. These effects are qualitatively similar to the ordering in figures $5 \mathrm{c}$ and $5 \mathrm{~d}$, but quantitatively the effects are smaller. Figures $6 \mathrm{c}$ and $6 \mathrm{~d}$ show the response of a similar shock in the goods sector. The results are qualitatively similar to the ordering in figures $5 \mathrm{a}$ and $5 \mathrm{~b}$ but again the quantitative response is smaller, in particular under a Taylor rule. Even though the ordering matters for the quantitative responses, fluctuations in wage-markups in the service sector have a larger effect on the CPI than similar shocks in the goods sector. However, in quantitative terms the effect is not large. 


\subsection{Sensitivity Analysis}

The sensitivity analysis is performed with respect to adjustment costs in prices, capital and wages, habit formation and parameter values. Like the adjustment costs in capital and prices, the adjustment cost in wages is assumed to be quadratic; that is,

$$
\frac{\kappa_{w_{1}}}{2}\left(\frac{W_{1, t}^{i}}{W_{1, t-1}^{i}}-\bar{\pi}_{1}\right)^{2} w_{1, t}^{i} .
$$

The adjustment cost in consumption is modelled through an assumption of habit formation

$$
U(\cdot)=\alpha \ln \left(c_{t}^{i}-\psi c_{t-1}^{i}\right)+(1-\alpha) \ln \ell_{t}^{i},
$$

where $\psi$ denotes the weight the household attaches to past consumption.

In order to study the sensitivity of the elasticity of substitution between goods and services we generalize the consumption aggregator in the following way

$$
c_{t}^{i}=\left(\alpha_{1}\left(c_{1, t}^{i}\right)^{\frac{\eta-1}{\eta}}+\left(1-\alpha_{1}\right)\left(c_{2, t}^{i}\right)^{\frac{\eta-1}{\eta}}\right)^{\frac{\eta}{\eta-1}},
$$

where $\eta$ denotes elasticity of substitution between goods and services. By assuming a CobbDouglas aggregator we have implicitly assumed this parameter to be one in the simulations.

The price adjustment cost parameter is set to make firms change the price once a year on average, both in the goods and the service sector. The parameter determining the cost of adjusting capital is taken from our benchmark calibration, that is; $\kappa_{k_{1}}$ and $\kappa_{k_{2}}$ are set equal to 4.50. The habit formation parameter is set to 0.7 , which we believe is a high number. The wage adjustment cost parameter in both sectors is set to make the nominal wage change every 1.5 years on average.

Figure 7 shows the response of the CPI to a 1 percent permanent shock to the wage-markup in the goods sector. The solid line in figure 7a shows the CPI in the benchmark model while the dashed line shows the CPI in the benchmark model augmented with price stickiness. Price 
stickiness have a small mitigating effect on the CPI. Quantitatively the effect is 0.02 percentage points. Capital adjustment costs and habit formation also have small effects on the CPI as shown in figures $7 \mathrm{~b}$ and $7 \mathrm{c}$. However, in contrast to price stickiness they tend to increase the response of the CPI somewhat. The effect of wage stickiness is harder to interpret since the wage-markup is endogenous in this experiment. As can be seen in figure $7 \mathrm{~d}$ the increase in the wage-markup is dampened initially and it takes about 10-15 periods before it reaches 1 percent. It is therefore hard to judge explicitly how important wage stickiness is to wage-markup shocks. Indeed, since the wage-markup is endogenous it is in fact impossible to actually talk about shocks to the wage-markup.

Figure 8 shows the results from the sensitivity analysis with respect to the parameter values. Figure 8a shows the sensitivity of the parameter that determines the size of the sectors; that is, $\alpha_{1}$. In the data, this parameter is 0.45 . By assuming a lower value, $\alpha_{1}=0.35$, the impact on the CPI is mitigated from 0.22 to 0.17 percentage points. On the other hand, if $\alpha_{1}=0.55$, the CPI increases to 0.27 percentage points. Figure $8 \mathrm{~b}$ shows sensitivity of the results to variations in $\omega_{2}$ in the shopping time technology. A higher $\omega_{2}$ mitigates the effects on the CPI of a wage-markup shock. Quantitatively the effect is not large. If $\omega_{2}$ is doubled, from 1.0 to 2.0 , the CPI falls from 0.22 to 0.20 percentage points. In figure $8 \mathrm{c}$ the sensitivity of the capital share parameter in the goods sector, $\theta_{1}$, is displayed. By lowering $\theta_{1}$ from 0.48 to 0.38 the CPI falls from 0.22 to 0.19 percentage points. Changes in $\theta_{2}$ have almost no impact on the CPI since the shock takes place in the goods sector. The results are therefore not shown. Finally, figure $8 \mathrm{~d}$ displays the results from varying the elasticity of substitution between goods and services between 0.5 and 2.0. Quantitatively, these effects are also small. Varying the other parameters, $\alpha, \beta, \delta_{1}, \delta_{2}$ and $\omega_{1}$ have even smaller effects on the CPI. They are therefore not shown.

The sensitivity analysis has shown that adjustment costs and changes in the parameter values 
affect the impact of a wage-markup shock. However, quantitatively the magnitude is not of the order of the relative price effect or active monetary policy (i.e. a Taylor rule versus a constant money supply rule).

\section{Conclusions}

Much of the empirical evidence suggests that wage increases do not lead to inflation. Hess and Schweitzer (2000) have summarized this evidence. In this paper we have demonstrated that a 2-sector DGE model calibrated to the U.S. economy is able to explain this empirical evidence. The mechanisms emphasized and quantified are changes in relative prices and monetary policy.

Monetary policy is important in mitigating shocks to wage-markups. The effects of a 1 percent increase in the wage-markup is quantified. By following a Taylor rule instead of a constant money supply rule, inflation is reduced by about 0.20 percentage points. Even more important are relative price changes. The relative price effect dampens inflation by 0.30 percentage points. All in all a 1 percent increase in the wage-markups leads to an increase in the CPI by no more than 0.10 percentage points if the monetary authority follows a Taylor rule. The results are somewhat sensitive to in which sector the shock occurs. Fluctuations in wage-markups in the service sector are somewhat more important for understanding the behavior of the inflation rate than similar shocks in the goods sector. In quantitative terms the effect is not large though.

The results are relatively insensitive to adjustment costs for prices, capital, habit formation in preferences and to reasonable changes of our calibrated parameter values. We therefore conclude that our framework is successful in replicating the empirical evidence stressed by Hess and Schweitzer (2000).

There are a number of interesting ways in which our analysis can be extended. The labor market is modelled in a very stylized way. Introducing a more realistic wage-bargaining problem 
and search and matching framework á la Pissarides (2000) are presumably interesting areas for future research. The framework developed by Ebell and Haefke (2003) looks particularly promising in this respect. Monetary policy has been modelled by simple rules. Studying how optimal policy would affect the results could also be an interesting extension of this paper. Tools for analyzing optimal policy in a model with imperfect competition have recently been developed by Schmitt-Grohe and Uribe (2004). 


\section{Appendix}

\section{A Data Used in the Calibrations}

This appendix describes the data used calibrate the model and calculate the empirical moments in table 2 and 3. All data refers to the period 1960-2001. We let goods equal durables and non-durables and services equal services where applicable. When the data is defined by industry groups we define the goods producing sector as consisting of the following sectors:

1. Agriculture, Forestry, and Fishing

2. Mining

3. Construction

4. Manufacturing

Whereas the service producing sector consists of the following sectors:

1. Transportation and Public Utilities

2. Wholesale Trade

3. Retail Trade

4. Finance, insurance, and real estate

5. Services

Defined this way, our two sectors broadly correspond to the production of goods and services as measured by the I/O tables. 


\section{A.1 Variables from NIPA tables}

$C_{1}, C_{2}$ : Real consumption of goods (durables and non-durables) and services in 1996 USD as reported in Table 1.2 .

$H_{1}, H_{2}$ : Hours worked in goods and service sector as reported in Tables $6.9 \mathrm{~B}+\mathrm{C}$.

$W_{1} H_{1}, W_{2} H_{2}$ : Nominal compensation of employees as reported in Tables $6.2 \mathrm{~B}+\mathrm{C}$.

$p_{2}$ : The ratio of the implicit price deflators for services relative to goods from Table 7.1.

All NIPA tables are available at www.bea.gov

\section{A.2 Variables from Fixed Assets tables}

$I_{1}, I_{2}$ : real investments in the goods and service sector in 1996 USD as measured by the historical cost investments reported in Table 3.7ES.

$\delta_{1}, \delta_{2}$ : real depreciation rates as measured by the current cost depreciation in 1996 USD in Table 3.4ES divided by the current cost net stock of capital in 1996 USD in Table 3.1ES, both of which are deflated by the difference between the Current-Cost Net Stock of Private Fixed Assets by Industry in Table 3.1ES (converted into an index series with 1996=100) and the Chain-Type Quantity Indexes for Depreciation of Private Fixed Assets by Industry in Table 3.5ES.

All Fixed Assets tables are available at www.bea.gov

\section{A.3 Variables from Other Sources}

$M$ : Stock of M2 money from the Federal Reserve Board of Governors, www.federalreserve.gov 
$P^{C P I}$ : CPI for all urban consumers from the Bureau of Labor Statistics,

www.bls.gov

\section{A.4 Variables Constructed by Us}

$Y_{1}, Y_{2}$ : The sum of consumption and investment in each sector

$K_{1}, K_{2}$ : Initial stocks of capital as measured by the deflated current cost net stock of capital from Table 3.1.S of the Fixed Assets tables plus real investments less the depreciation as defined above.

$W_{1}, W_{2}$ : Nominal compensation divided by hours worked

$\pi^{C P I}$ : Annual change in the CPI

$\pi^{*}$ : Weighted average of CPI-inflation and nominal wage increases 


\section{References}

Aaronson, Daniel (2001), "Price Pass-Through and the Minimum Wage," The Review of Economic Studies 83, 158-169.

Bils, Mark and Peter Klenow (2002), "Some Evidence on the Importance of Sticky Prices," NBER Working Paper No. 9069.

Blanchard, Olivier and Nobuhiro Kiyotaki (1987), "Monopolistic Competition and the Effects of Aggregate Demand," American Economic Review 77, 647-66.

Calvo, Guillermo (1983), "Staggered Prices in an Utility-Maximizing Framework," Journal of Monetary Economics 12, 383-98.

Clark, Todd (1997), "Do Producer Prices Help Predict Consumer Prices," Federal Reserve Bank of Kansas City Research Paper No.97-09.

Cooley, Thomas and Ed Prescott (1995), "Economic Growth and the Business Cycle," in Thomas Cooley (ed.), Frontiers of Business Cycle Research, Princeton University Press, 1-38.

Dib, Ali (2002), "Nominal Rigidities and Monetary Policy in Canada Since 1981," Bank of Canada Working Paper 2002-25.

Dixon Huw and Neil Rankin (1994), "Imperfect Competition and Macroeconomics: A Survey," Oxford Economic Papers 46, 171-199.

Ebell, Monique and Christian Haefke (2003), "Product Market Deregulation and Labor Market Outcomes," mimeo.

Galí, Jordi, Mark Gertler, and David López-Salido (2000), "Markups, Gaps, and the Welfare Costs of Business Fluctuations," NBER Working Paper No. 8850.

Ghali, Khalifa (1999), "Wage Growth and the Inflation Process: A Multivariate Cointegration Analysis," Journal of Money, Credit and Banking, 31, 417-31.

Hess, Gregory and Mark Schweitzer (2000), "Does Wage Inflation Cause Price Inflation?," Federal Reserve Bank of Cleveland Policy Discussion Paper No. 10.

Hogan, Vincent (1998), "Explaining the Recent Behavior of Inflation and Unemployment in the United States," IMF Working Paper No. 98/145.

Hornstein, Andreas (1993), "Monopolistic Competition, Increasing Returns to Scale, and the Importance of Productivity Shocks," Journal of Monetary Economics 31, 299-316.

Ireland, Peter (2001), "Sticky Price Models of the Business Cycle: Specification and Stability," Journal of Monetary Economics 47, 3-18.

Juster, Thomas and Frank Stafford (1991), "The Allocation of Time: Empirical Findings, Behavior Models, and Problems of Measurement," Journal of Economic Literature 29, 471-522.

Layard, Richard, Stephen Nickell, and Richard Jackman (1994), The Unemployment Crisis, Oxford University Press.

Ljungqvist, Lars and Thomas Sargent (2000), Recursive Macroeconomic Theory, MIT Press.

Mankiw, Gregory and Ricardo Reis (2002), "What Measure of Inflation should a Central Bank Target?," ECB Working Paper No. 170. 
Mehra, Yash (1993) "Unit Labor Costs and the Price Level," Federal Reserve Bank of Richmond Economic Review 79, 35-52.

Obstfeld, Maurice and Kenneth Rogoff (1996), Foundations of International Macroeconomics, MIT Press.

Pakko, Michael (1998), "Dynamic Shoe-Leather Costs in a Shopping-Time Model of Money," Federal Reserve Bank of St. Louis Working Paper 98-007.

Pissarides, Christopher (2000), Equilibrium Unemployment Theory, MIT Press.

Prescott, Edward (1986), "Theory Ahead of Business Cycle Measurement," Federal Reserve Bank of Minneapolis Quarterly Review 10, 9-22.

Rissman, Ellen (1995), "Sectoral Wage Growth and Inflation," Federal Reserve Bank of Chicago Economic Perspectives July/August, 16-28.

Rotemberg, Julio (1982), "Monopolistic Price Adjustment and Aggregate Output," Review of Economic Studies 49, 517-531.

Schmitt-Grohe, Stephanie and Martín Uribe (2004), "Optimal Fiscal and Monetary Policy under Imperfect Competition," Journal of Macroeconomics, forthcoming.

Taylor, John (1993), "Discretion versus Policy Rules in Practice," Carnegie-Rochester Series on Public Policy 39, 195-214.

Uhlig, Harald (1999), "A toolkit for analyzing nonlinear dynamic stochastic models easily," in Ramon Marimon and Andrew Scott (eds.), Computational Methods for the Study of Dynamic Economies, Oxford University Press. 
Table 1: Parameter values.

\begin{tabular}{c|l|c}
\hline \hline Parameter & Description & Value \\
\hline$\alpha$ & Weight on consumption relative to leisure & 0.38 \\
$\alpha_{1}$ & Weight on goods relative to services & 0.45 \\
$\beta$ & Discount factor & 0.96 \\
$\omega_{1}$ & Shopping time technology, scaling parameter & 0.01 \\
$\omega_{2}$ & Shopping time technology, curvature parameter & 1.00 \\
$\delta_{1}$ & Rate of depreciation in goods sector & 0.07 \\
$\delta_{2}$ & Rate of deprecation in service sector & 0.03 \\
$\theta_{1}$ & Capital share in goods sector & 0.48 \\
$\theta_{2}$ & Capital share in service sector & 0.38 \\
$\bar{\nu}_{p_{1}}$ & Price markup in goods sector & 1.22 \\
$\bar{\nu}_{p_{2}}$ & Price markup in service sector & 1.27 \\
$\bar{\nu}_{w_{1}}$ & Average wage markup in goods sector & 1.06 \\
$\bar{\nu}_{w_{2}}$ & Average wage markup in service sector & 1.09 \\
$\kappa_{p_{1}}$ & Price adjustment cost parameter, goods sector & 0.00 \\
$\kappa_{p_{2}}$ & Price adjustment cost parameter, service sector & 3.60 \\
$\kappa_{k_{1}}$ & Capital adjustment cost parameter, goods sector & 0.00 \\
$\kappa_{k_{2}}$ & Capital adjustment cost parameter, service sector & 4.50 \\
\hline \hline
\end{tabular}


Table 2: Simulated and empirical moments, benchmark model.

\begin{tabular}{lccc}
\hline \hline Moment & Constant $M^{S}$-rule & Taylor-rule & Empirical (60-01) \\
\hline$\sigma\left(\ln Y_{1, t}\right)$ & 0.023 & 0.023 & 0.026 \\
$\sigma\left(\ln Y_{2, t}\right)$ & 0.042 & 0.041 & 0.027 \\
$\sigma\left(\ln Y_{t}\right)$ & 0.028 & 0.027 & 0.026 \\
$\sigma\left(\ln C_{1, t}\right) / \sigma\left(\ln Y_{1, t}\right)$ & 0.24 & 0.24 & 0.98 \\
$\sigma\left(\ln C_{2, t}\right) / \sigma\left(\ln Y_{2, t}\right)$ & 0.13 & 0.11 & 0.41 \\
$\sigma\left(\ln C_{t}\right) / \sigma\left(\ln Y_{t}\right)$ & 0.20 & 0.20 & 0.65 \\
$\sigma\left(\ln I_{1, t}\right) / \sigma\left(\ln Y_{1, t}\right)$ & 2.96 & 3.12 & 3.86 \\
$\sigma\left(\ln I_{2, t}\right) / \sigma\left(\ln Y_{2, t}\right)$ & 5.90 & 6.13 & 3.57 \\
$\sigma\left(\ln I_{t}\right) / \sigma\left(\ln Y_{t}\right)$ & 4.13 & 4.38 & 3.15 \\
$\sigma\left(\ln H_{1, t}\right) / \sigma\left(\ln Y_{1, t}\right)$ & 0.50 & 0.48 & 0.89 \\
$\sigma\left(\ln H_{2, t}\right) / \sigma\left(\ln Y_{2, t}\right)$ & 0.58 & 0.56 & 0.75 \\
$\sigma\left(\ln H_{t}\right) / \sigma\left(\ln Y_{t}\right)$ & 0.53 & 0.49 & 0.84 \\
$\rho\left(\ln Y_{1, t}, \ln C_{1, t}\right)$ & 0.70 & 0.43 & 0.90 \\
$\rho\left(\ln Y_{2, t}, \ln C_{2, t}\right)$ & 0.61 & 0.31 & 0.80 \\
$\rho\left(\ln Y_{t}, \ln C_{t}\right)$ & 0.40 & 0.04 & 0.91 \\
$\rho\left(\ln Y_{1, t}, \ln I_{1, t}\right)$ & 0.99 & 0.99 & 0.49 \\
$\rho\left(\ln Y_{2, t}, \ln I_{2, t}\right)$ & 0.99 & 0.99 & 0.97 \\
$\rho\left(\ln Y_{t}, \ln I_{t}\right)$ & 0.99 & 0.99 & 0.92 \\
$\rho\left(\ln Y_{1, t}, \ln H_{1, t}\right)$ & 0.94 & 0.91 & 0.88 \\
$\rho\left(\ln Y_{2, t}, \ln H_{2, t}\right)$ & 0.98 & 0.98 & 0.74 \\
$\rho\left(\ln Y_{t}, \ln H_{t}\right)$ & 0.97 & 0.96 & 0.84 \\
$\rho\left(\pi_{t}^{C P I}, \ln Y_{t}\right)$ & -0.76 & 0.02 & -0.08 \\
$\rho\left(\pi_{t}^{C P I}, \ln \left(M_{t} / P_{t}\right)\right)$ & 0.48 & -0.86 & -0.36 \\
\hline$\rho\left(\pi_{t}^{C P I}, \ln \nu_{w_{1}, t}\right)$ & 0.11 & -0.38 & 0.29 \\
$\rho\left(\pi_{t}^{C P I}, \ln \nu_{w_{2}, t}\right)$ & 0.77 & 0.44 & 0.71 \\
\hline$\rho\left(\pi_{t}^{C P I}, \Delta \ln W_{t}\right)$ & -0.66 & 0.19 & 0.66 \\
$\rho\left(\pi_{t}^{C P I}, \Delta \ln W_{1, t}\right)$ & -0.66 & 0.19 & 0.62 \\
$\rho\left(\pi_{t}^{C P I}, \Delta \ln W_{2, t}\right)$ & -0.65 & 0.21 & 0.61 \\
$\sigma\left(\Delta \ln W_{t}\right) / \sigma\left(\pi_{t}^{C P I}\right)$ & 1.48 & 0.84 & 0.71 \\
$\sigma\left(\Delta \ln W_{1, t}\right) / \sigma\left(\pi_{t}^{C P I}\right)$ & 1.47 & 0.84 & 0.91 \\
$\sigma\left(\Delta \ln W_{2, t}\right) / \sigma\left(\pi_{t}^{C P I}\right)$ & 1.46 & 0.43 & 0.69 \\
$\sigma\left(\ln w_{1, t}\right) / \sigma\left(\ln Y_{1, t}\right)$ & 0.39 & 0.23 & 0.59 \\
$\sigma\left(\ln w_{2, t}\right) / \sigma\left(\ln Y_{2, t}\right)$ & 0.21 & & 0.42 \\
\hline \hline Nots The & & & \\
\hline
\end{tabular}

Notes: The first column shows the moment we are looking at, where $\sigma$ refers to the standard deviation of the variable, and $\rho$ refers to the correlation between two variables. The second and third column show the simulated moments from the model. Statistics for the model economy are computed on HP detrended data generated by simulating the model for 200 periods and repeating the simulation 300 times (each sample is initiated with 100 extra observations which are then discarded). The statistics are then averages over these 300 simulations. The final column shows the corresponding moments in the data measured as percent deviation from a HP-filter trend. 
Table 3: Simulated and empirical moments, adjustment cost model.

\begin{tabular}{lccc}
\hline \hline Moment & Constant $M^{S}$-rule & Taylor-rule & Empirical (60-01) \\
\hline$\sigma\left(\ln Y_{1, t}\right)$ & 0.026 & 0.025 & 0.026 \\
$\sigma\left(\ln Y_{2, t}\right)$ & 0.023 & 0.023 & 0.027 \\
$\sigma\left(\ln Y_{t}\right)$ & 0.019 & 0.019 & 0.026 \\
$\sigma\left(\ln C_{1, t}\right) / \sigma\left(\ln Y_{1, t}\right)$ & 0.23 & 0.23 & 0.98 \\
$\sigma\left(\ln C_{2, t}\right) / \sigma\left(\ln Y_{2, t}\right)$ & 0.52 & 0.52 & 0.41 \\
$\sigma\left(\ln C_{t}\right) / \sigma\left(\ln Y_{t}\right)$ & 0.31 & 0.30 & 0.65 \\
$\sigma\left(\ln I_{1, t}\right) / \sigma\left(\ln Y_{1, t}\right)$ & 2.97 & 3.00 & 3.86 \\
$\sigma\left(\ln I_{2, t}\right) / \sigma\left(\ln Y_{2, t}\right)$ & 3.57 & 3.57 & 3.57 \\
$\sigma\left(\ln I_{t}\right) / \sigma\left(\ln Y_{t}\right)$ & 3.70 & 3.75 & 3.15 \\
$\sigma\left(\ln H_{1, t}\right) / \sigma\left(\ln Y_{1, t}\right)$ & 0.57 & 0.56 & 0.89 \\
$\sigma\left(\ln H_{2, t}\right) / \sigma\left(\ln Y_{2, t}\right)$ & 0.32 & 0.31 & 0.75 \\
$\sigma\left(\ln H_{t}\right) / \sigma\left(\ln Y_{t}\right)$ & 0.39 & 0.39 & 0.84 \\
$\rho\left(\ln Y_{1, t}, \ln C_{1, t}\right)$ & 0.71 & 0.66 & 0.90 \\
$\rho\left(\ln Y_{2, t}, \ln C_{2, t}\right)$ & 0.99 & 0.99 & 0.80 \\
$\rho\left(\ln Y_{t}, \ln C_{t}\right)$ & 0.70 & 0.67 & 0.91 \\
$\rho\left(\ln Y_{1, t}, \ln I_{1, t}\right)$ & 0.99 & 0.99 & 0.49 \\
$\rho\left(\ln Y_{2, t}, \ln I_{2, t}\right)$ & 0.99 & 0.99 & 0.97 \\
$\rho\left(\ln Y_{t}, \ln I_{t}\right)$ & 0.98 & 0.98 & 0.92 \\
$\rho\left(\ln Y_{1, t}, \ln H_{1, t}\right)$ & 0.96 & 0.96 & 0.88 \\
$\rho\left(\ln Y_{2, t}, \ln H_{2, t}\right)$ & -0.10 & -0.02 & 0.74 \\
$\rho\left(\ln Y_{t}, \ln H_{t}\right)$ & 0.87 & 0.87 & 0.84 \\
$\rho\left(\pi_{t}^{C P I}, \ln Y_{t}\right)$ & -0.40 & -0.31 & -0.08 \\
$\rho\left(\pi_{t}^{C P I}, \ln \left(M_{t} / P_{t}\right)\right)$ & 0.58 & -0.07 & -0.36 \\
\hline$\rho\left(\pi_{t}^{C P I}, \ln \nu_{w_{1}, t}\right)$ & 0.05 & 0.02 & 0.29 \\
$\rho\left(\pi_{t}^{C P I}, \ln \nu_{w_{2}, t}\right)$ & 0.78 & 0.71 & 0.71 \\
\hline$\rho\left(\pi_{t}^{C P I}, \Delta \ln W_{t}\right)$ & 0.49 & 0.38 & 0.66 \\
$\rho\left(\pi_{t}^{C P I}, \Delta \ln W_{1, t}\right)$ & 0.47 & 0.36 & 0.62 \\
$\rho\left(\pi_{t}^{C P I}, \Delta \ln W_{2, t}\right)$ & 0.47 & 0.37 & 0.61 \\
$\sigma\left(\Delta \ln W_{t}\right) / \sigma\left(\pi_{t}^{C P I}\right)$ & 0.73 & 0.75 & 0.71 \\
$\sigma\left(\Delta \ln W_{1, t}\right) / \sigma\left(\pi_{t}^{C P I}\right)$ & 0.72 & 0.76 & 0.91 \\
$\sigma\left(\Delta \ln W_{2, t}\right) / \sigma\left(\pi_{t}^{C P I}\right)$ & 0.73 & 0.36 & 0.59 \\
$\sigma\left(\ln w_{1, t}\right) / \sigma\left(\ln Y_{1, t}\right)$ & 0.31 & 0.35 & 0.42 \\
$\sigma\left(\ln w_{2, t}\right) / \sigma\left(\ln Y_{2, t}\right)$ & 0.32 & \\
\hline \hline Nots The & & & \\
\hline
\end{tabular}

Notes: The first column shows the moment we are looking at, where $\sigma$ refers to the standard deviation of the variable, and $\rho$ refers to the correlation between two variables. The second and third column show the simulated moments from the model. Statistics for the model economy are computed on HP detrended data generated by simulating the model for 200 periods and repeating the simulation 300 times (each sample is initiated with 100 extra observations which are then discarded). The statistics are then averages over these 300 simulations. The final column shows the corresponding moments in the data measured as percent deviation from a HP-filter trend. 
Fig. 1a

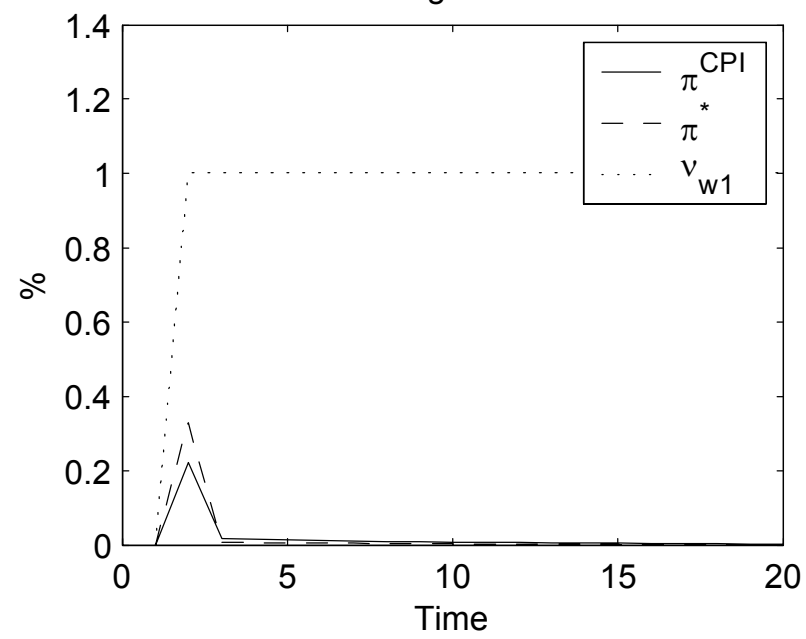

Fig. 1c

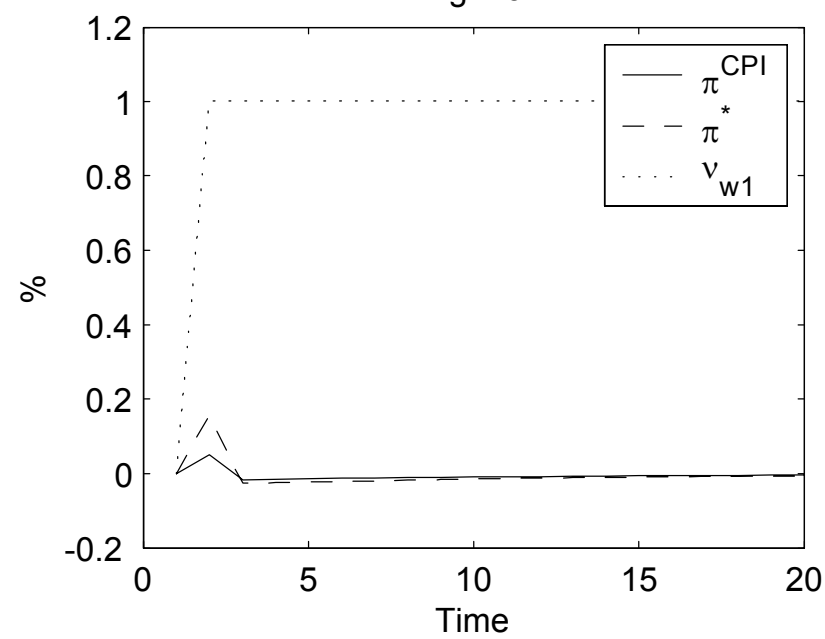

Fig. 1b

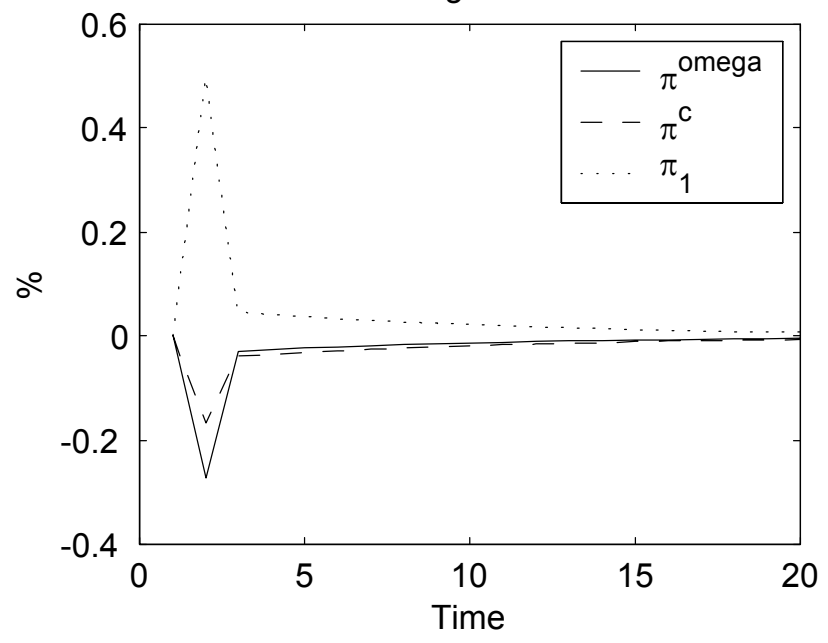

Fig. 1d

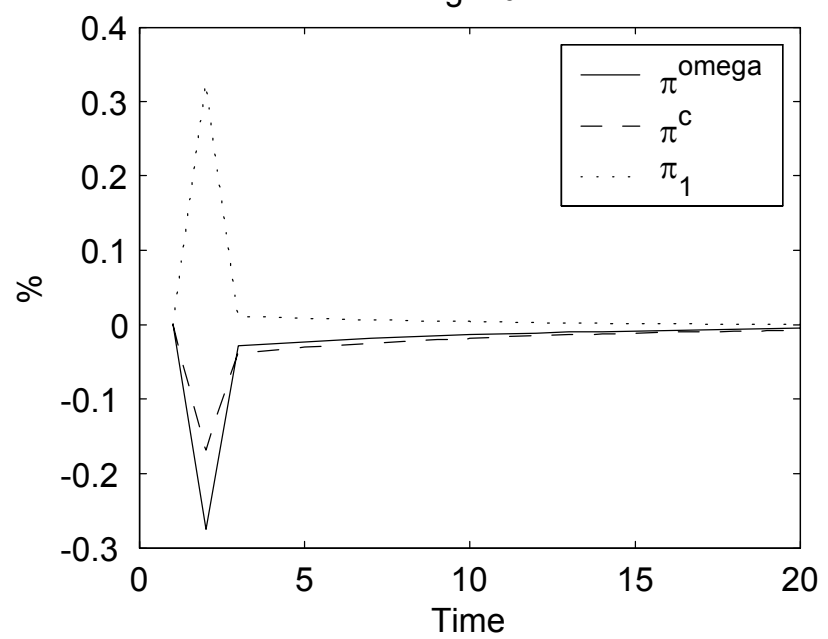

Figure 1: A 1 percent wage-markup shock in the goods sector in the benchmark model. Figures $1 \mathrm{a}$ and $1 \mathrm{~b}$ under a constant money supply rule and $1 \mathrm{c}$ and $1 \mathrm{~d}$ under a Taylor rule. 
Fig. 2a

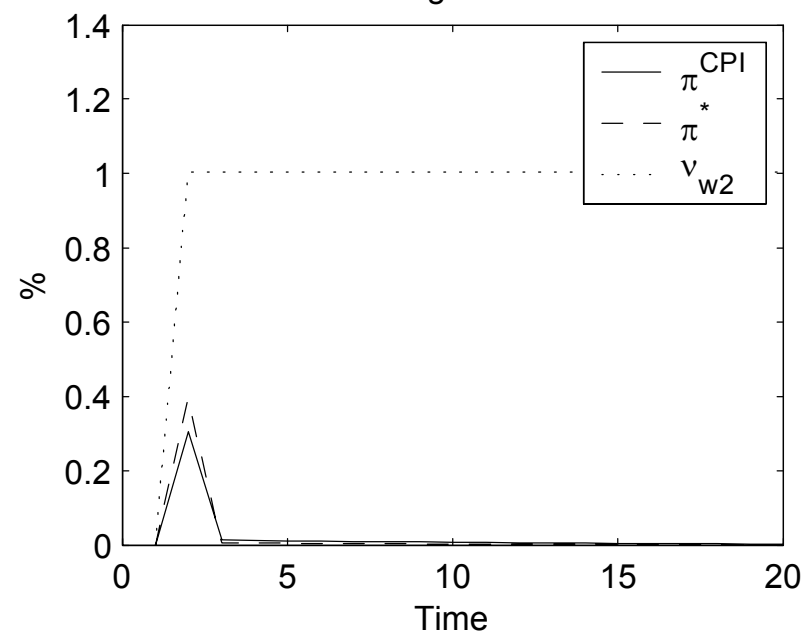

Fig. 2c

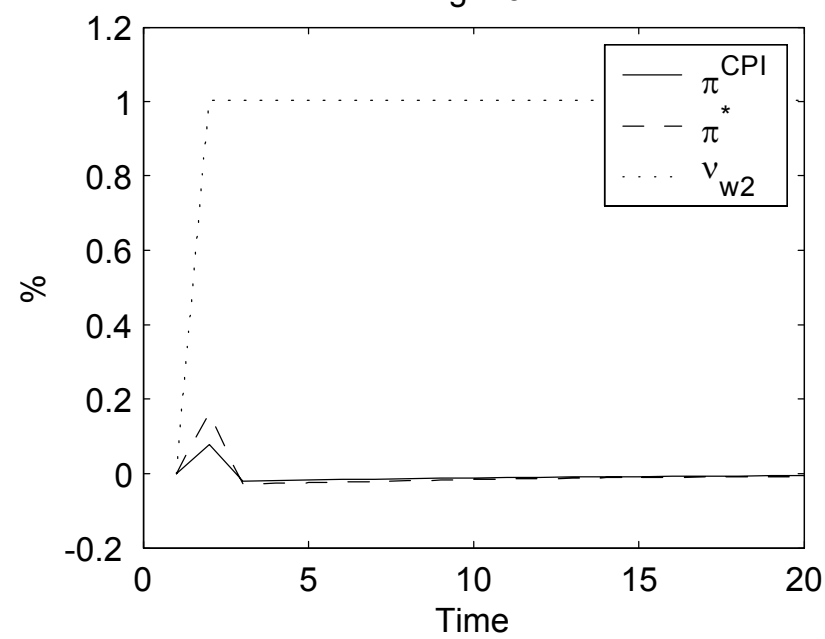

Fig. $2 b$

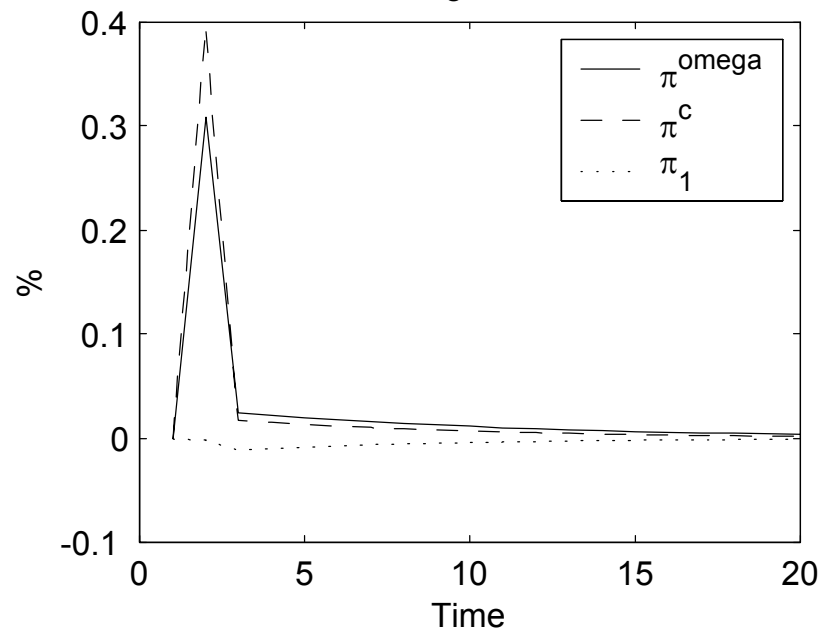

Fig. 2d

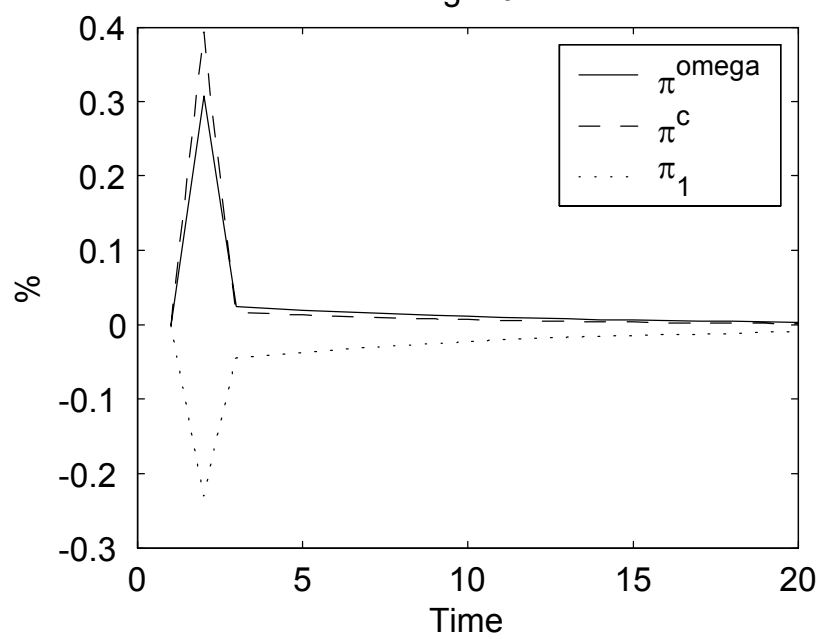

Figure 2: A 1 percent wage-markup shock in the service sector in the benchmark model. Figures $2 \mathrm{a}$ and $2 \mathrm{~b}$ under a constant money supply rule and $2 \mathrm{c}$ and $2 \mathrm{~d}$ under a Taylor rule. 
Fig. 3a

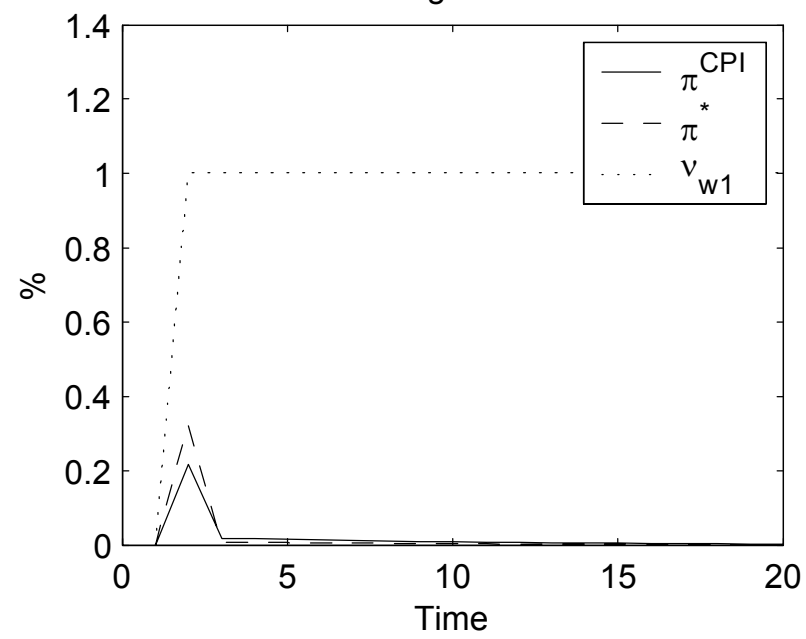

Fig. 3c

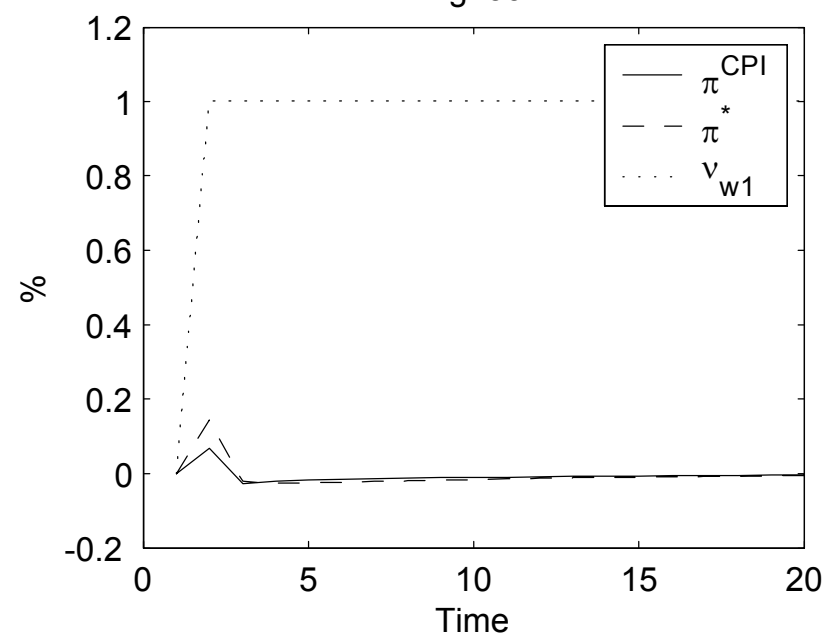

Fig. $3 b$

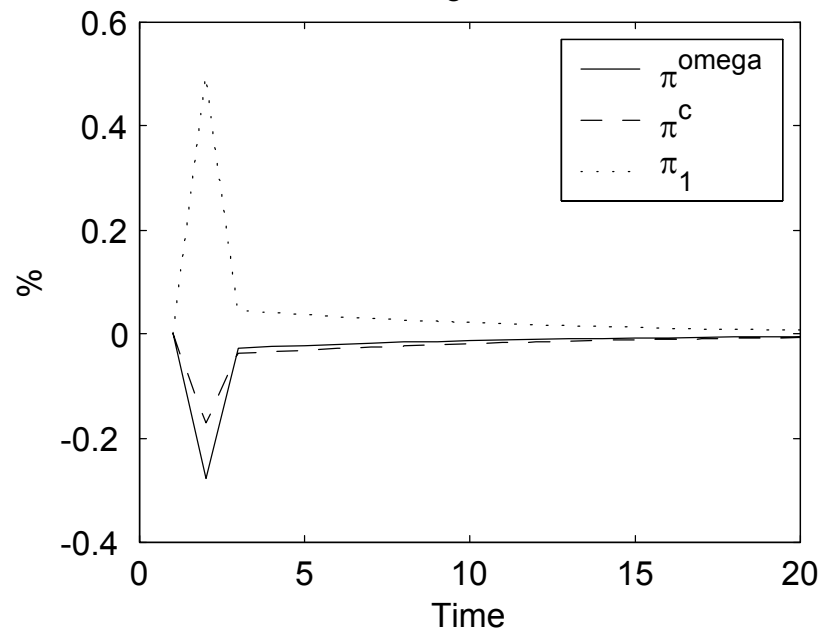

Fig. 3d

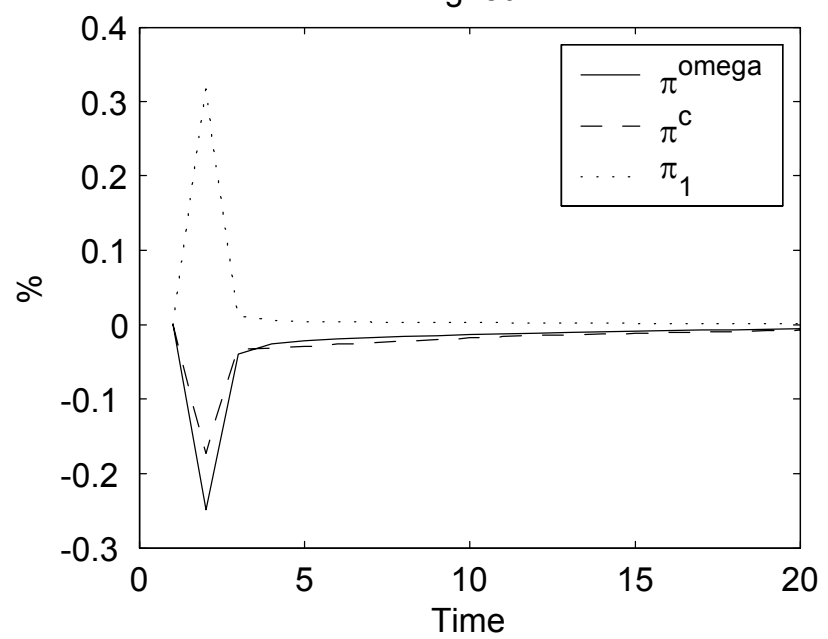

Figure 3: A 1 percent wage-markup shock in the goods sector in the adjustment cost model.

Figures $3 \mathrm{a}$ and $3 \mathrm{~b}$ under a constant money supply rule and $3 \mathrm{c}$ and $3 \mathrm{~d}$ under a Taylor rule. 
Fig. $4 a$

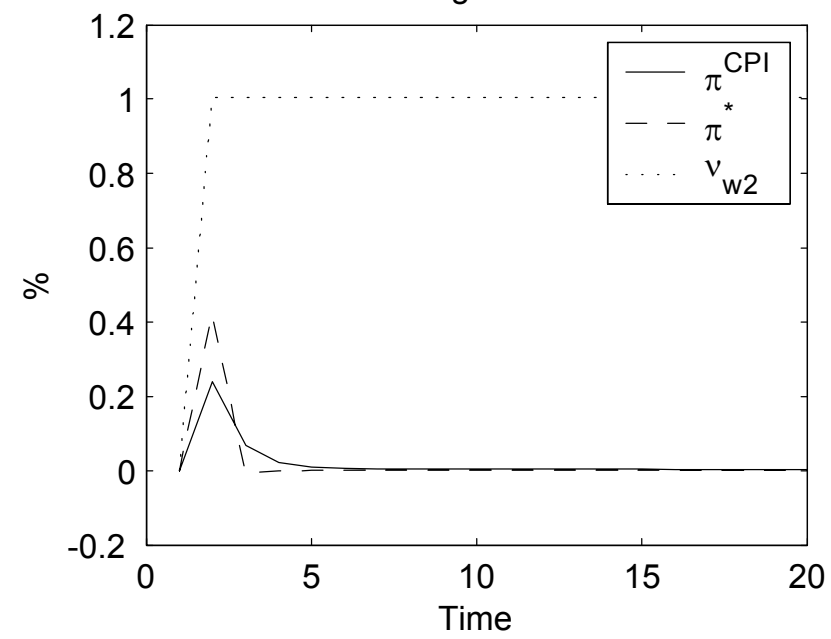

Fig. 4c

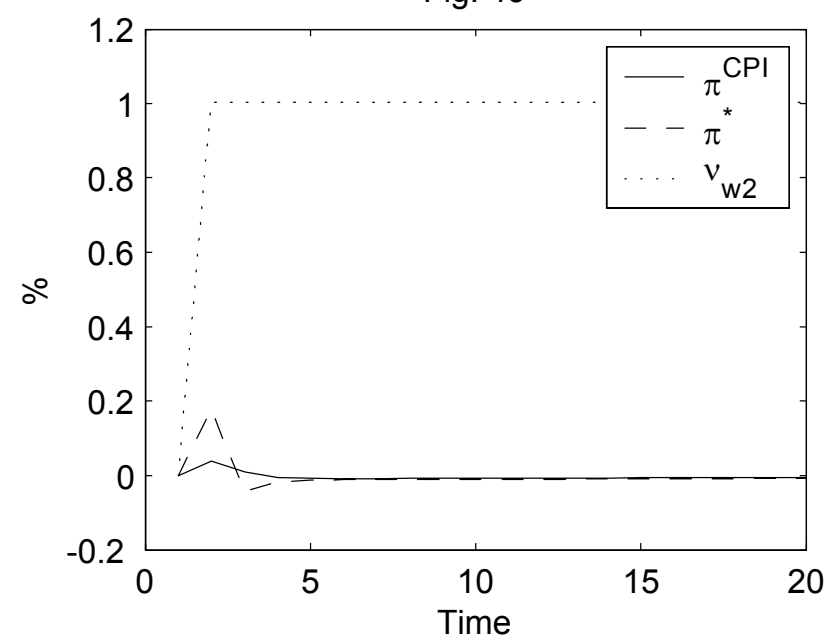

Fig. $4 b$

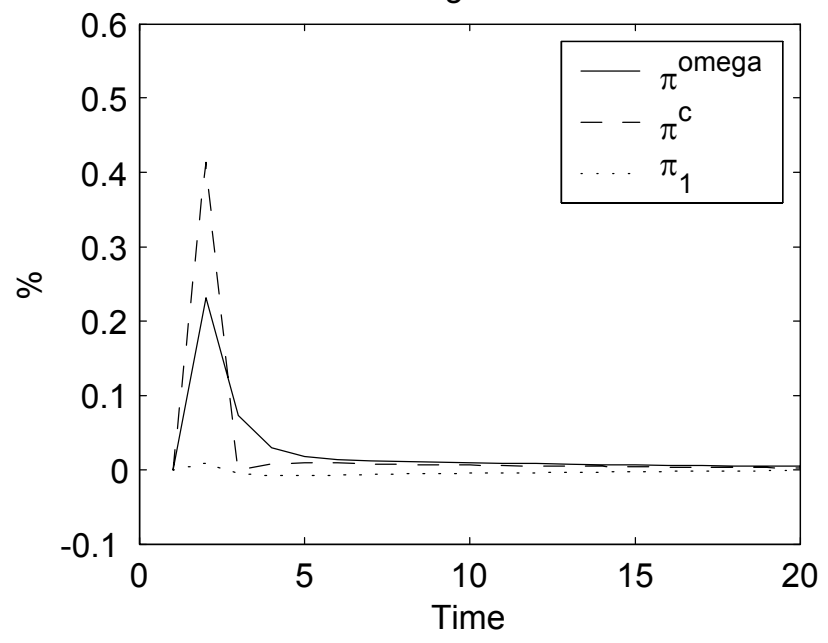

Fig. 4d

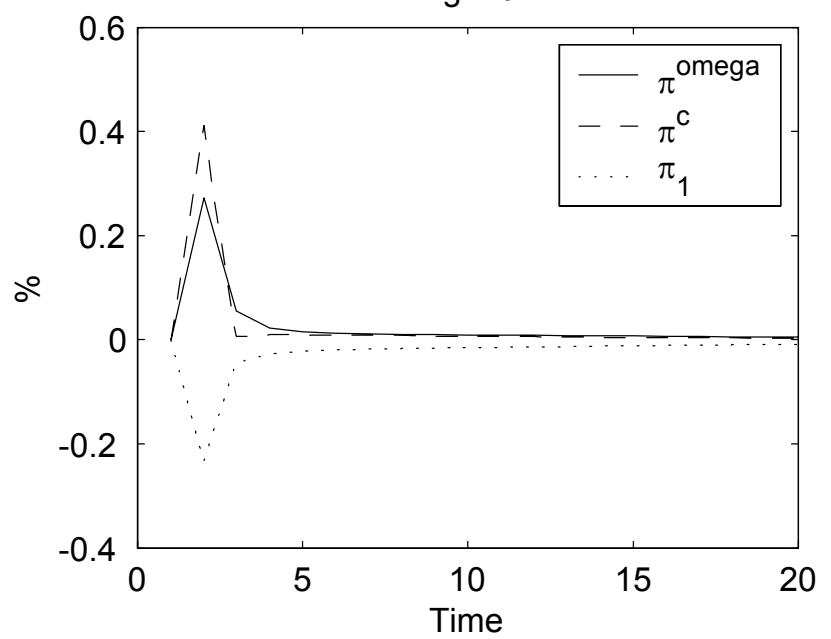

Figure 4: A 1 percent wage-markup shock in the service sector in the adjustment cost model.

Figures $4 \mathrm{a}$ and $4 \mathrm{~b}$ under a constant money supply rule and $4 \mathrm{c}$ and $4 \mathrm{~d}$ under a Taylor rule. 
Fig. 5a

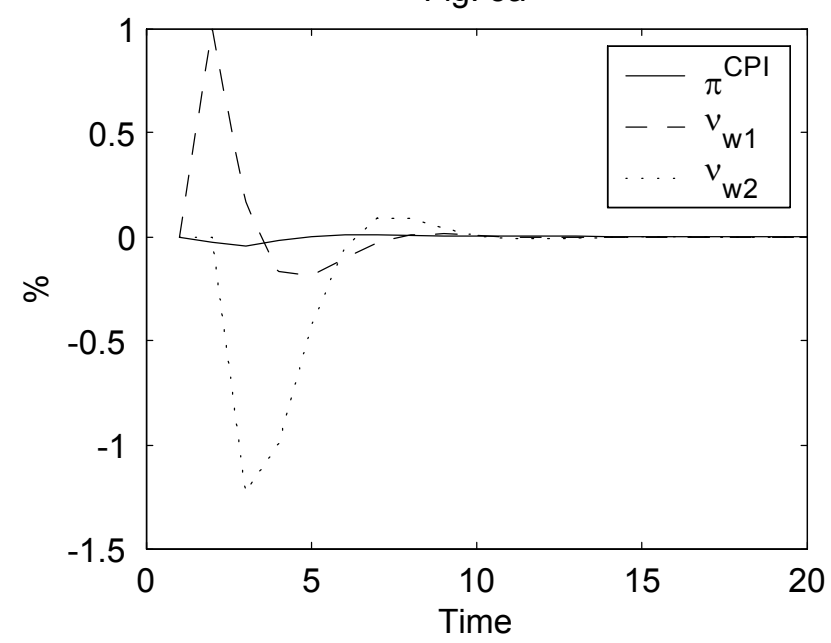

Fig. 5c

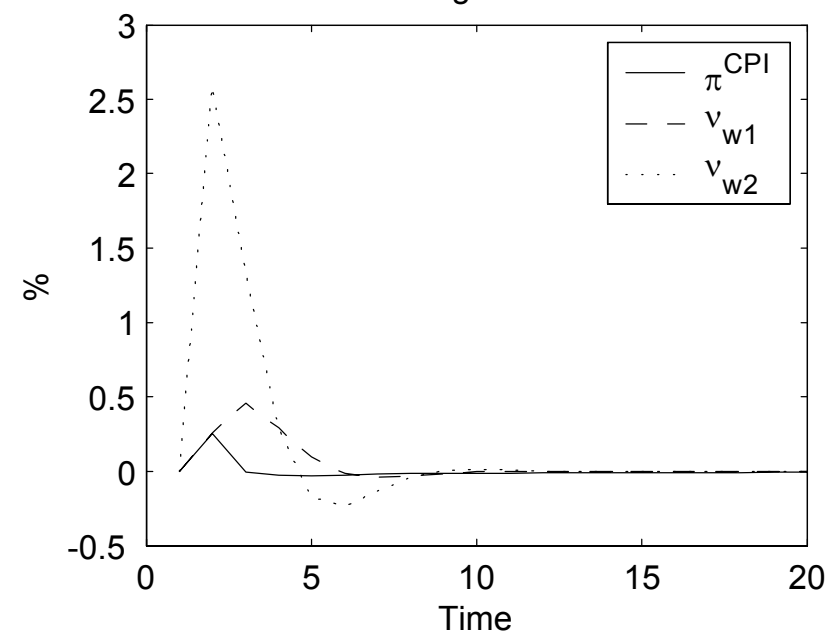

Fig. $5 b$

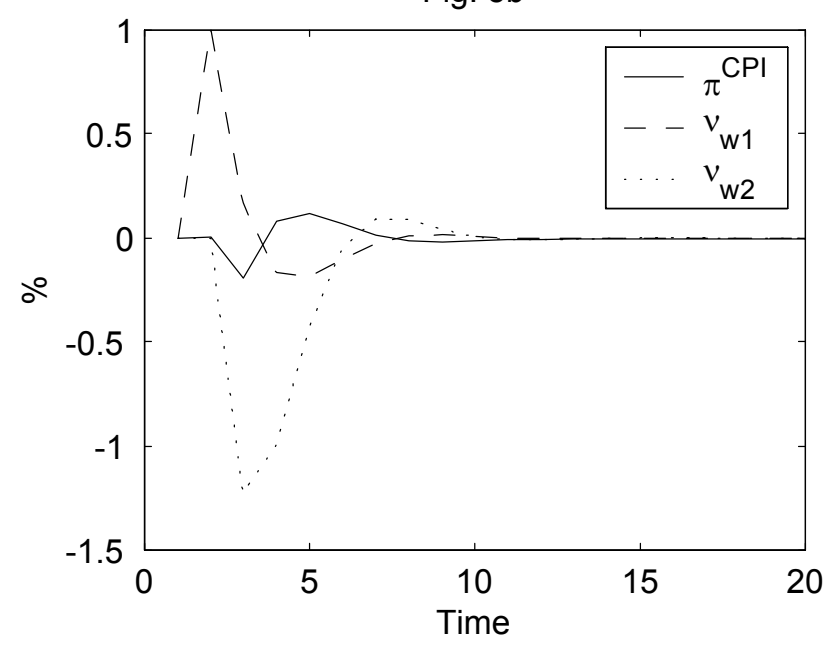

Fig. $5 d$

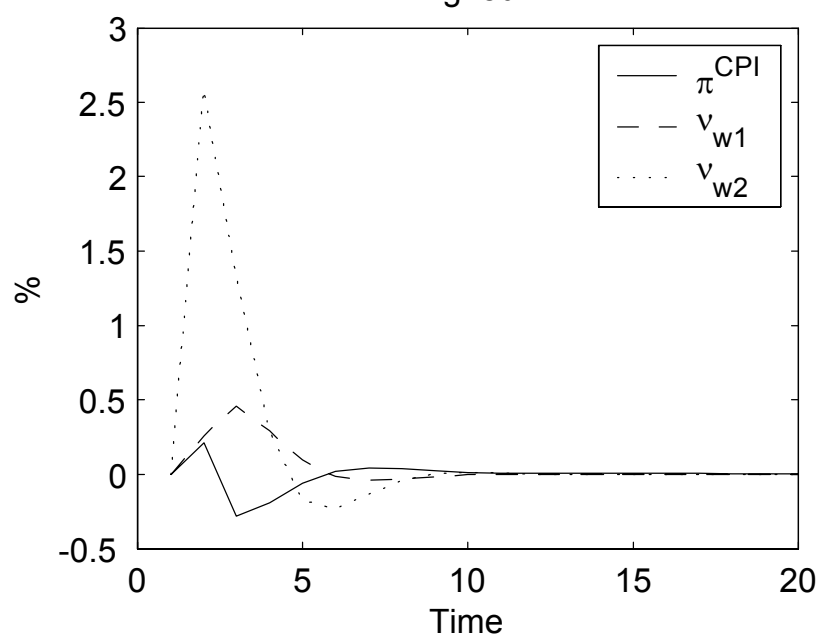

Figure 5: A wage-markup shock in the goods sector, 5a and 5b, and the service sector, 5c and $5 \mathrm{~d}$, from the VAR-model. Figures $5 \mathrm{a}$ and $5 \mathrm{c}$ show the results under a constant money supply rule and figures $5 \mathrm{~b}$ and $5 \mathrm{~d}$ under a Taylor rule. 
Fig. $6 a$

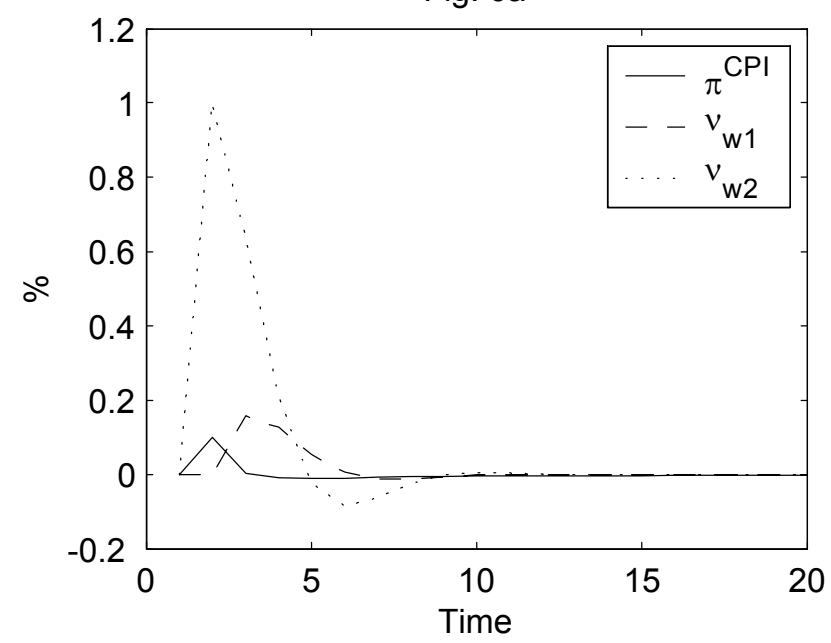

Fig. 6c

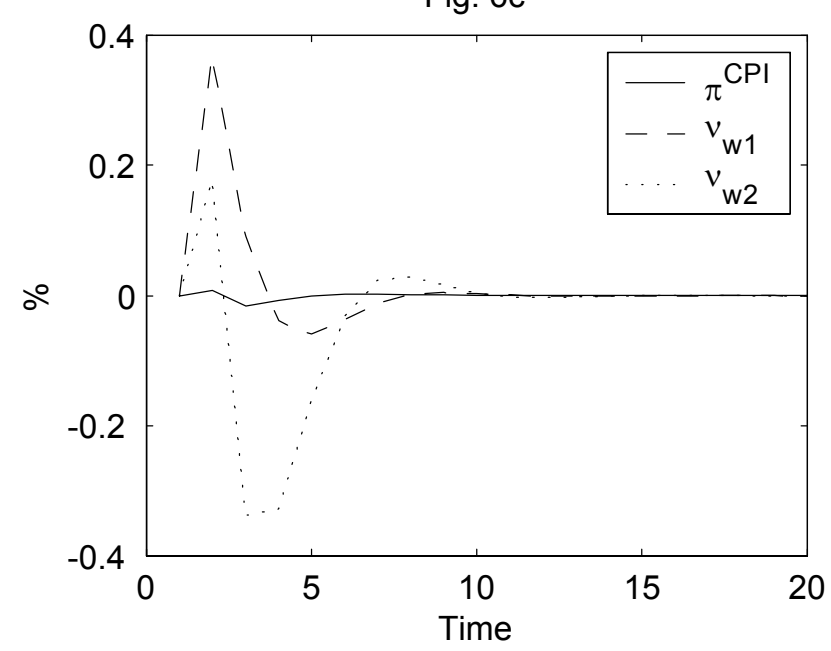

Fig. $6 b$

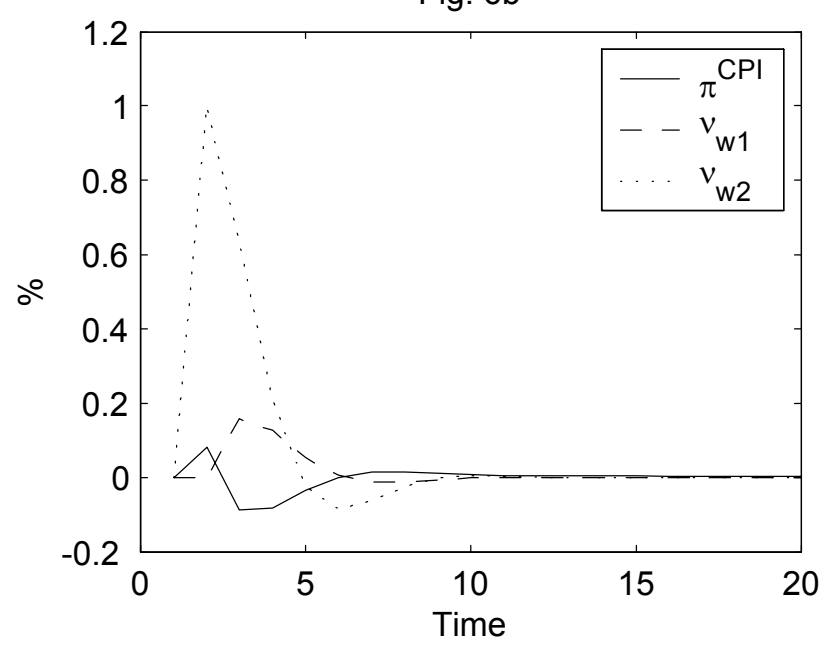

Fig. 6d

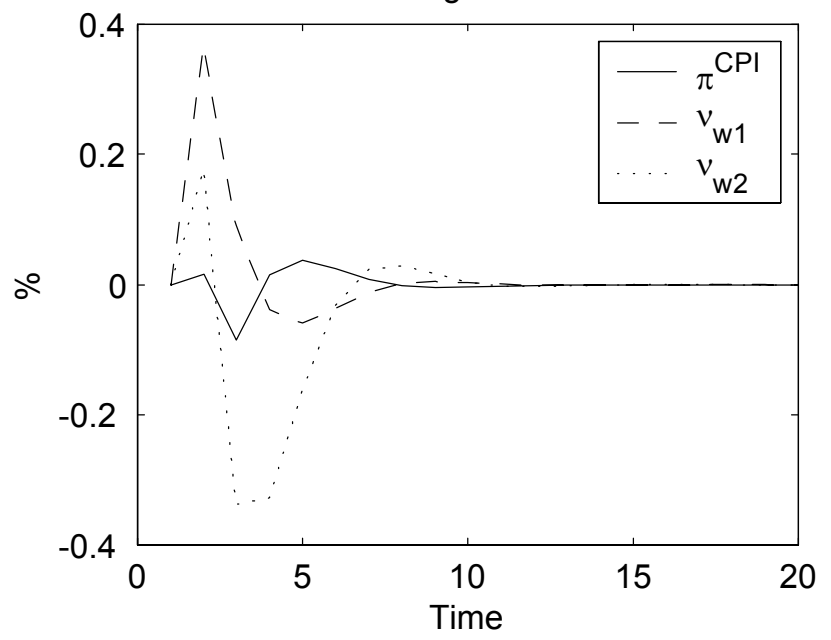

Figure 6: A wage-markup shock in the goods sector, 6a and 6b, and the service sector, $6 \mathrm{c}$ and $6 \mathrm{~d}$, from the VAR-model. Figures $6 \mathrm{a}$ and $6 \mathrm{c}$ show the results under a constant money supply rule and figures $6 \mathrm{~b}$ and $6 \mathrm{~d}$ under a Taylor rule. 
Fig. $7 a$

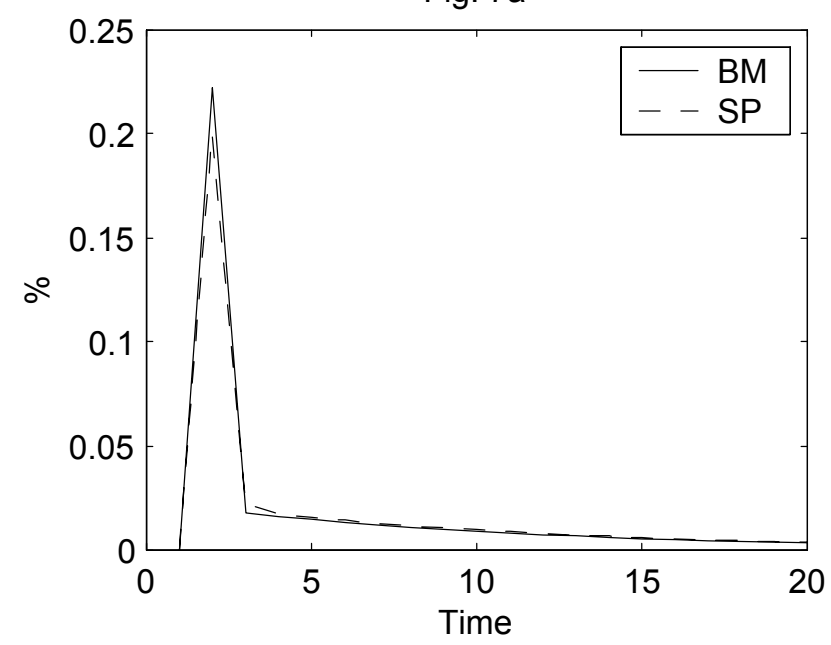

Fig. 7c

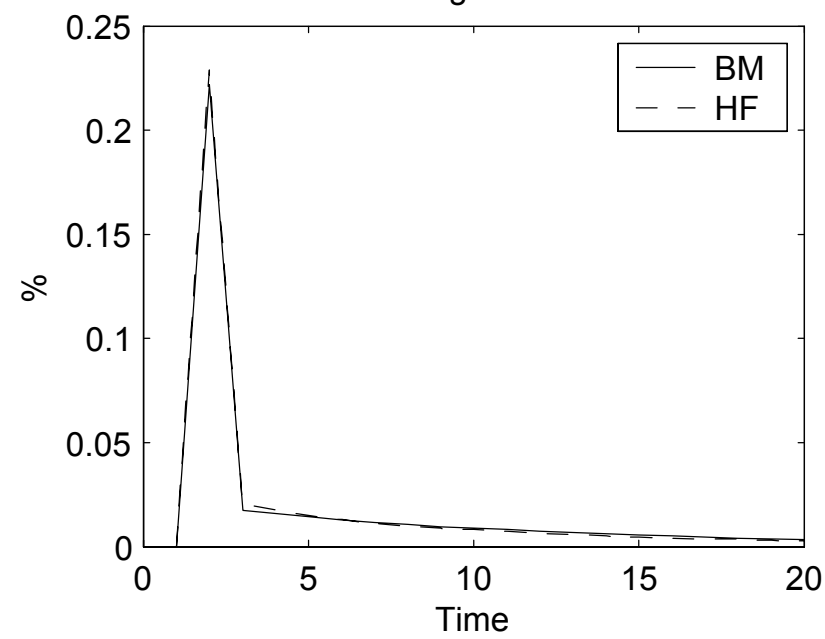

Fig. $7 b$

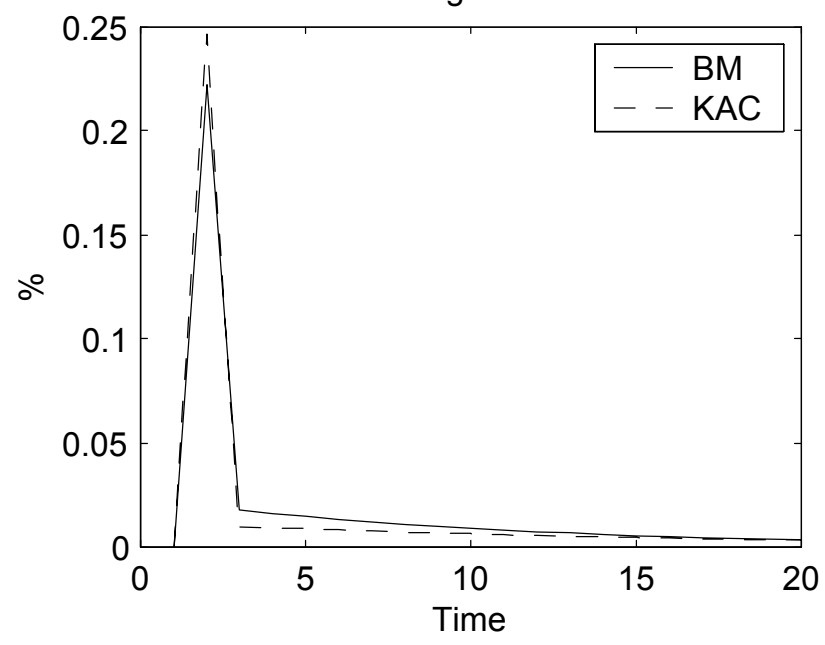

Fig. $7 d$

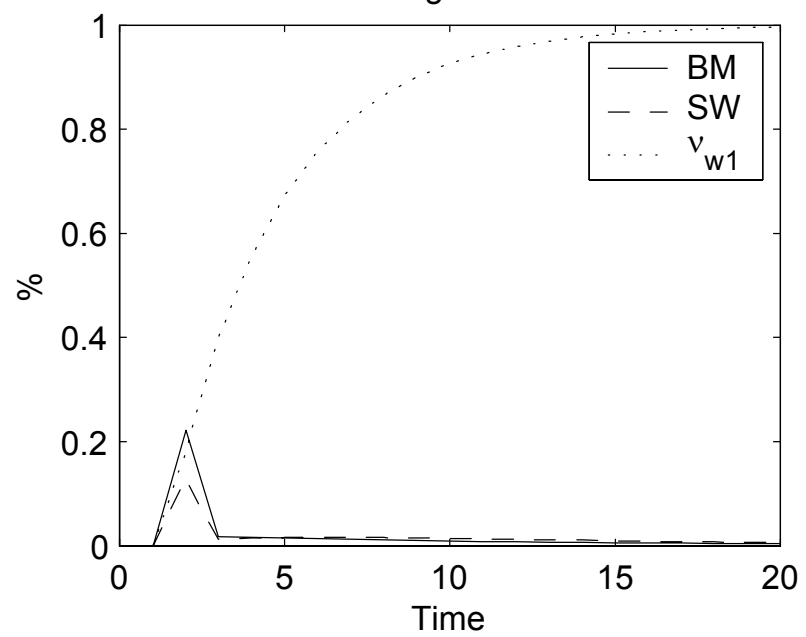

Figure 7: Sensitivity analysis of a wage-markup shock on the inflation rate (CPI). BM denotes benchmark model, SP sticky prices, KAC capital adjustment costs, HF habit formation and SW sticky wages. 
Fig. $8 a$

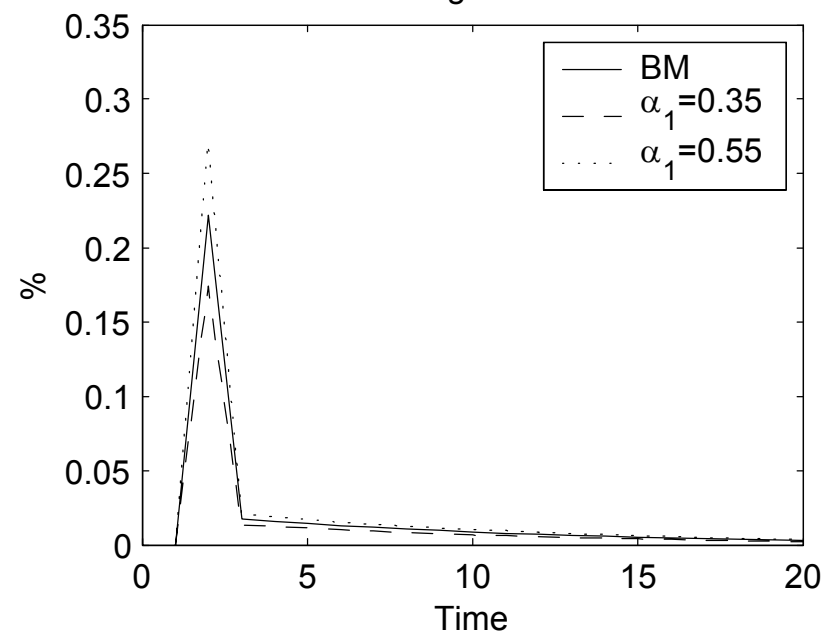

Fig. 8c

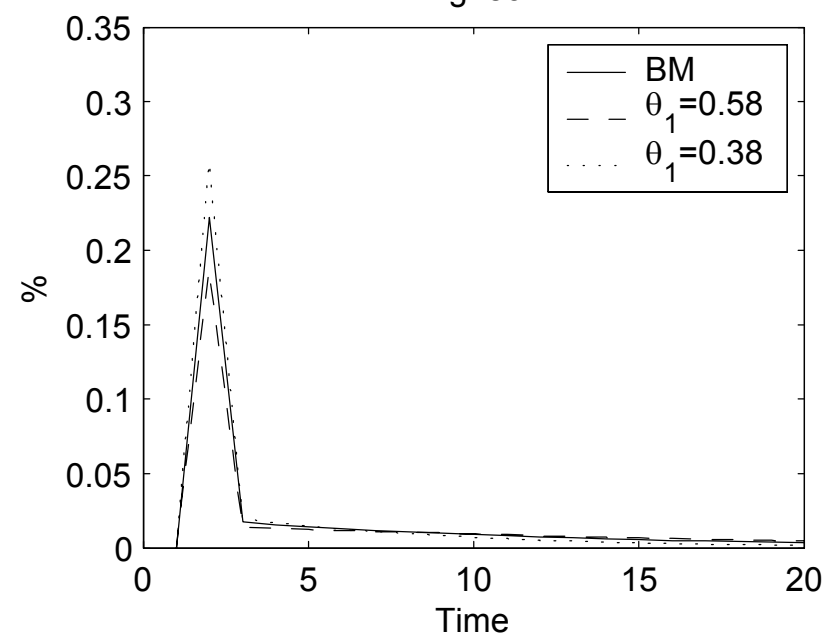

Fig. $8 b$

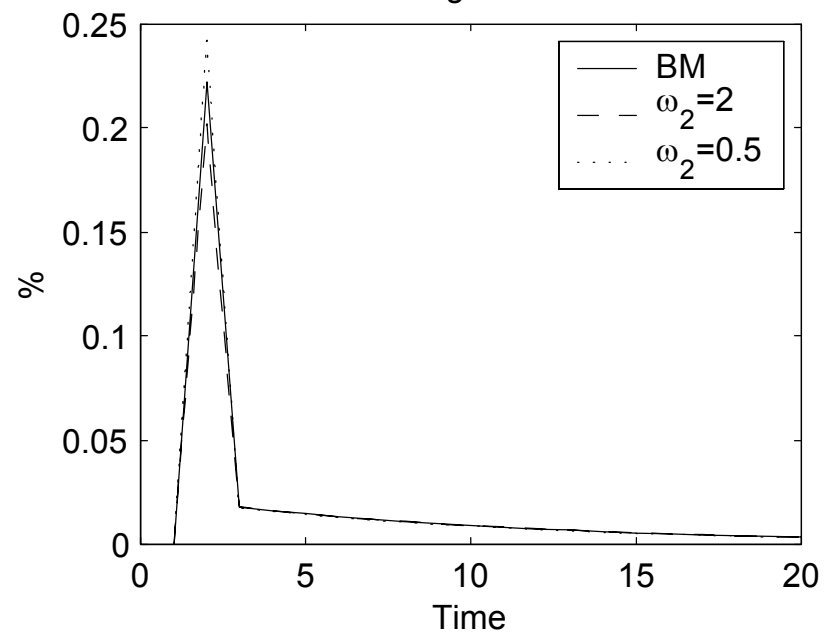

Fig. 8d

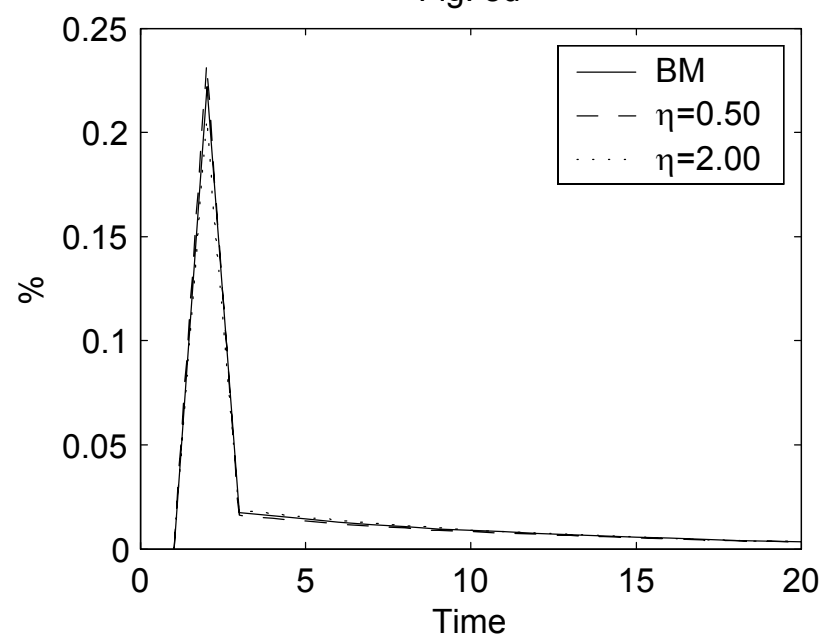

Figure 8: Sensitivity analysis of a wage-markup shock on the inflation rate (CPI) with respect to variations in the parameter values. 


\section{Earlier Working Papers:}

Inflation Forecast Targeting: the Swedish Experience by Claes Berg . 2000:100

Wage Effects of Mobility, Unemployment Benefits and Benefit Financing

by Hans Lindblad. 2000:101

A Bivariate Distribution for Inflation and Output Forecasts

by Mårten Blix and Peter Sellin .... 2000:102

Optimal Horizons for Inflation Targeting

by Nicoletta Batini and Edward Nelson. 2000:103

Empirical Estimation and the Quarterly Projection Model:

An Example Focusing on the External Sector

by Robert Amano, Don Coletti and Stephen Murchison

Conduction Monetary Policy with a Collegial Bord:

The New Swedish Legislation One Year On by Claes Berg and Hans Lindberg

Price-level targeting versus inflation targeting in a forward-looking model

by David Vestin

Unemployment and Inflation Regimes by Anders Vredin and Anders Warne 2000:107

An Expectations-Augmented Phillips Curve in an Open Economy by Kerstin Hallsten 2000:108

An alternative interpretation of the recent U.S. inflation performance

by Mikael Apel and Per Jansson.... 2000:109

Core inflation and monetary policy by Marianne Nessén and UIf Söderström 2000:110

Estimating the Implied Distribution of the Future Short-Term Interest Rate

Using the Longstaff-Schwartz Model by Peter Hördahl. 2000:111

Financial Variables and the Conduct of Monetary Policy

by Charles Goodhart and Boris Hofmann

Testing for the Lucas Critique: A Quantitative Investigation by Jesper Lindé ................................. 2000:113

Monetary Policy Analysis in Backward-Looking Models by Jesper Lindé....................................... 2000:114

UIP for short investments in long-term bonds by Annika Alexius ................................................. 2000:115

Qualitative Survey Responses and Production over the Business Cycle

by Tomas Lindström

Supply stocks and real exchange rates by Annika Alexius ..................................................... 2000:117

Casuality and Regime Inference in a Markov Switching VAR by Anders Warne ........................... 2000:118

Average Inflation Targeting by Marianne Nessén and David Vestin ............................................ 2000:119

Forecast-based monetary policy in Sweden 1992-1998: A view from within

by Per Jansson and Anders Vredin ......................................................................... 2000:120

What have we learned from empirical tests of the monetary transmission effect?

by Stefan Norrbin

Simple monetary policy rules and exchange rate uncertainty

by Kai Leitemo and UIf Söderström

Targeting inflation with a prominent role for money

by Ulf Söderström

Is the Short-run Phillips Curve Nonlinear? Empirical Evidence for Australia, Sweden

and the United States by Ann-Charlotte Eliasson

An Alternative Explanation of the Price Puzzle by Paolo Giordani ............................................. 2001:125

Interoperability and Network Externalities in Electronic Payments by Gabriela Guibourg................ 2001:126

Monetary Policy with Incomplete Exchange Rate Pass-Through by Malin Adolfson ...................... 2001:127

Micro Foundations of Macroeconomic Price Adjustment: Survey Evidence from

Swedish Firms by Mikael Apel, Richard Friberg and Kerstin Hallsten....

Estimating New-Keynesian Phillips Curves on Data with Measurement Errors:

A Full Information Maximum Likelihood Approach by Jesper Lindé

The Empirical Relevance of Simple Forward- and Backward-looking Models:

A View from a Dynamic General Equilibrium Model by Jesper Lindé

Diversification and Delegation in Firms by Vittoria Cerasi and Sonja Daltung 2001:131

Monetary Policy Signaling and Movements in the Swedish Term Structure of Interest Rates

by Malin Andersson, Hans Dillén and Peter Sellin ....

Evaluation of exchange rate forecasts for the krona's nominal effective exchange rate by Henrik Degrér, Jan Hansen and Peter Sellin .... 
Implications of Exchange Rate Objectives under Incomplete Exchange Rate Pass-Through by Malin Adolfson

Incomplete Exchange Pass-Through and Simple Monetary Policy Rules

by Malin Adolfson

Financial Instability and Monetary Policy: The Swedish Evidence

by U. Michael Bergman and Jan Hansen ....

Finding Good Predictors for Inflation: A Bayesian Model Averaging Approach

by Tor Jacobson and Sune Karlsson .....

How Important Is Precommitment for Monetary Policy?

by Richard Dennis and Ulf Söderström

Can a Calibrated New-Keynesian Model of Monetary Policy Fit the Facts?

by Ulf Söderström, Paul Söderlind and Anders Vredin ....

Inflation Targeting and the Dynamics of the Transmission Mechanism

by Hans Dillén.

Capital Charges under Basel II: Corporate Credit Risk Modelling and the Macro Economy

by Kenneth Carling, Tor Jacobson, Jesper Lindé and Kasper Roszbach ....

Capital Adjustment Patterns in Swedish Manufacturing Firms: What Model Do They Suggest?

by Mikael Carlsson and Stefan Laséen

Bank Lending, Geographical Distance, and Credit risk: An Empirical Assessment

of the Church Tower Principle by Kenneth Carling and Sofia Lundberg

Inflation, Exchange Rates and PPP in a Multivariate Panel Cointegration Model

by Tor Jacobson, Johan Lyhagen, Rolf Larsson and Marianne Nessén

Evaluating Implied RNDs by some New Confidence Interval Estimation Techniques

by Magnus Andersson and Magnus Lomakka 2003:146

Taylor Rules and the Predictability of Interest Rates

by Paul Söderlind, Ulf Söderström and Anders Vredin

Inflation, Markups and Monetary Policy

by Magnus Jonsson and Stefan Palmqvist.

Financial Cycles and Bankruptcies in the Nordic Countries by Jan Hansen ......

2003:149

Bayes Estimators of the Cointegration Space by Mattias Villani. 2003:150

Business Survey Data: Do They Help in Forecasting the Macro Economy?

by Jesper Hansson, Per Jansson and Mårten Löf....

The Equilibrium Rate of Unemployment and the Real Exchange Rate:

An Unobserved Components System Approach by Hans Lindblad and Peter Sellin 2003:152

Monetary Policy Shocks and Business Cycle Fluctuations in a

Small Open Economy: Sweden 1986-2002 by Jesper Lindé.

2003:153

Bank Lending Policy, Credit Scoring and the Survival of Loans by Kasper Roszbach. 2003:154

Internal Ratings Systems, Implied Credit Risk and the Consistency of Banks' Risk

Classification Policies by Tor Jacobson, Jesper Lindé and Kasper Roszbach

Monetary Policy Analysis in a Small Open Economy using Bayesian Cointegrated

Structural VARs by Mattias Villani and Anders Warne

Indicator Accuracy and Monetary Policy: Is Ignorance Bliss? by Kristoffer P. Nimark

2003:157

Intersectoral Wage Linkages in Sweden by Kent Friberg

2003:158 
Sveriges Riksbank

Visiting address: Brunkebergs torg 11

Mail address: se-103 37 Stockholm 